\title{
1. Actors and law-making in international environmental law
}

\author{
Mark A. Drumbl and Kateřina Uhlírová
}

\subsection{INTRODUCTION}

Strikingly diverse numbers of actors create international environmental law through strikingly diverse processes of law-making. The dynamism of actors and law-making in international environmental law contributes to similar developments in international law generally.

Traditionally, the number of actors with international legal personality - in other words, those actors who actually could make international law has been limited. States were primary among this group, followed by international organizations. In recent years, however, considerable international environmental law has been effectively generated by non-governmental organizations, networked communities of experts, and administrative secretariats of treaty organizations. Major international conferences of states serve important social constructivist functions in setting norms and building consensus.

The expansion in the number of actors that, whether de jure or de facto, make international environmental law has diversified the sources of international environmental law, thereby enriching the process by which it is made. Sources of international law include treaties, custom, general principles of law, and - in a subsidiary manner - judicial decisions and the writings of eminent publicists (Statute of the International Court of Justice (ICJ Statute), 1945: Article 38(1) and (2)). ${ }^{1}$ However, much of international environmental law is informally generated by 'soft law' - namely that which is 'not yet or not only law' (Dupuy, 1991: 420) - in particular when it comes to setting norms and defining agendas for formal law-making processes. International environmental law has seen a particularly dynamic element of soft law-making and, in this vein, has been an important trendsetter for the expanding content of international law generally. As a result, the epistemology of what constitutes international environmental law is indeed flowering and becoming more diverse.

This chapter explores in greater depth the following two questions:

1. Who makes international environmental law?

2. What are the sources of international environmental law?

Obviously, the intention here is not to cover every single actor or source of international environmental law. That would fill a treatise. Instead, it is to give a flavour of the types of actors involved, the types of sources of law implicated, and to provide some examples of each in order to offer readers an intelligible grounding. 


\subsection{WHO MAKES INTERNATIONAL ENVIRONMENTAL LAW?}

Traditionally, under basic principles of public international law, only a few actors actually have international legal personality. International legal personality 'involves the capacity to perform legal acts on the international plane rather than within a municipal law system' (Damrosch et al., 2001: 360). States have international legal personality. However, the concept of international legal personality has widened 'beyond the state' and, inter alia, applies to certain international organizations (Damrosch et al., 2001: 249-50). ${ }^{2}$ These entities thereby have the formal capacity to make international law.

However, a focus only on formal capacity to make international law does not do justice to the broad array of actors that are actually involved in the law-making process. Many non-traditional, non-formalized actors are very active in making international environmental law. Their involvement affects the way in which formal actors conduct themselves: what they say, the information they have, and what they agree upon. Consequently, in order truly to do justice to the actors involved in making international environmental law, this section explores both actors with formal capacity to make international law as well as actors who, although without formal capacity (or whose formal capacity remains debated), still exhibit an ability to influence, and in some cases to effect, international environmental law. Moreover, there is a growing need for states to cooperate with non-state actors in order to effectively protect common global interests (De Feyter, 2017). De Feyter points to an insufficient protection of common global interests in current international law and locates a need for global cooperation especially in the fields of sustainable development, biological diversity, and climate change (De Feyter, 2017).

\subsubsection{States}

A state is a sovereign entity with a permanent population, defined territory and its own government, that engages in, or has the capacity to engage in, formal relationships with other states. At the time of writing, 193 states are members of the United Nations (UN), with the latest arrival being South Sudan in $2011 .^{3}$

States are the primary actors in formulating international environmental law. States negotiate, adopt, sign, ratify, and then implement international conventions, treaties, and protocols - including multilateral environmental agreements (MEAs). Moreover, state behaviour undertaken out of a sense of legal obligation creates customary international law. Insofar as international treaties and custom are the most important sources of international environmental law, states remain the most important actors in international environmental law. Paradoxically, just as states are the most important actors formulating international environmental law, states also can serve as the most important source of international environmental problems. States create the problems that, in turn, they seek, or are called upon, to rectify through law. States also affect the content of international environmental law through the domestic laws they pass.

Political, economic, and geographic differences among states account for some of the major fissures in international environmental law-making. These differences deeply affect the areas on which there is substantive agreement and the overall tenor of diplomatic discussions. These differences also explain many of the compromises that have been made in the content of international environmental instruments. 


\section{Research handbook on international environmental law}

One of the broadest divides in international environmental law-making has little to do with the environment per se but, instead, has to do with economic development. This is the divide between industrialized and industrializing states. 'At the global level, major differences in development patterns between industrialized and developing countries have led to generally different approaches to international environmental issues' (Hunter, Salzman and Zaelke, 2007: 163; see also: Drumbl, 2002: 845-8). Industrialized countries include the United States (US), Canada, Australia, New Zealand, states in Europe (including the states emergent from the former Soviet bloc), and Japan. Although not all located in the 'North', this term has emerged as a moniker for such states.

Industrializing countries are referred to as the 'South'. As a general rule,

many countries in the South believe that harmonizing environmental standards through global environmental agreements would slow their development and unreasonably limit their economic growth to respond to problems caused predominantly by the insatiable consumption of the North. (Hunter, Salzman and Zaelke, 2007: 163)

Because many natural resources are located in the South, it retains a 'bargaining chip' in global environmental negotiations with the North that it does not have in other issue areas. Citizens of these states may also face considerable local environmental and health challenges, including air and water pollution and concerns over indoor air quality. This has given rise to a principle entitled 'common but differentiated responsibilities', which this chapter discusses in greater depth further on.

The South is deeply heterogeneous (Brown, 1994: 356). It includes states such as Rwanda and Malawi, with 2016 per capita GDPs of US\$2000 and US\$1200 respectively, and states such as China, Brazil, Argentina, and South Korea, with per capita GDPs of US\$15,700, US\$15,500, US\$20,400 and US\$38,400 respectively (CIA World Factbook). ${ }^{4}$ Accordingly, states with wildly differing levels of economic development and short-term growth potential comprise the South. Many 'Southern' states are industrializing rapidly and produce large quantities of environmentally harmful emissions. For example, among the top emitters (measured according to all the fossil fuels burned and cement produced in each nation, converted into $\mathrm{CO}_{2}$ ): China: 9697 million tonnes (MT) or 28.6 per cent, US: 5420 MT or 16.0 per cent, India: 1967 MT or 5.8 per cent, Russia: 1829 MT or 5.4 per cent, Japan: 1243 MT or 3.7 per cent, Germany: 810 MT or 2.4 per cent, South Korea: 609 MT or 1.7 per cent, Canada: 555 MT or 1.6 per cent (data compiled by the Netherlands Environmental Assessment Agency in 2011; see Clark, 2011).

The identification, both politically and legally, of a meaningful partnership between the North and the South is pivotal to the operationalization and future of international environmental law. This partnership, elsewhere referred to as a 'shared compact' (Drumbl, 2002: 843 ), implicates many other important principles of international environmental law.

Divides between developed and developing nations are not the only ones that affect the tenor of international environmental law-making. For example, negotiations regarding the United Nations Convention on the Law of the Sea (UNCLOS), and the development of customary international law reflected in UNCLOS, were affected by conflicts between states with coastlines and landlocked states. Climate change negotiations are affected by tensions between oil-producing states, many of which are in the South, and states with extensive low-lying territories and small island states, many of which also are in the South. Within the North, there is a divide between Europe, on the one hand, and the US, Canada, and Australia, on the 
other, regarding biosafety and biotechnology, owing to divergent agricultural methods. ${ }^{5}$ The US and Europe are often not aligned with regard to international environmental law-making. Although affected in some part by differences regarding environmental policy, this divide is also generated by political and social differences between the US and Europe in terms of attitudes toward international legalization generally. That said, considerable political volatility exists within each of the US and Europe in matters of international environmental policy. The Trump administration, for example, has reversed many of the political pushes that the Obama administration had initiated and concluded.

\subsubsection{International Organizations}

Generally speaking, international organizations are created by states. They are, therefore, intergovernmental in origin but may be granted their own international legal personality. Indicators of international legal personality are such things as constitutive documents (usually treaties) that create organs with powers of their own and that treat the organization as separate from its members. Most international organizations that have international legal personality derive it expressly from their constitutive documents. The constitutive documents of some international organizations, even if they do not expressly accord the organization with international legal personality, can impliedly be read to accord such personality (see Damrosch et al., 2001: 361; Kirgis, 1993). ${ }^{6}$ Such personality may also be implied from how the organization interacts and conducts its activities. However, even if an international organization falls short of formally having international legal personality, and cannot be implied to have such personality, it still may act effectively to formulate international law. International organizations also can initiate processes, raise awareness, share information, and create opportunities for states to assemble where they, in turn, formulate law. This facilitative role is very important.

The principal international organization with international legal personality is the United Nations (see ICJ Advisory Opinion on Reparation for Injuries Suffered in the Service of the United Nations, 1949: 174). Important elements of the United Nations' work are articulated through two of its key organs, the United Nations Security Council and the United Nations General Assembly. In addition, a number of specialized international organizations have mandates that touch upon environmental matters. International organizations are staffed by delegates representing states and also by independent civil servants who work for and report to the organization itself. The fact that certain international organizations strive towards specific institutional mandates means they may proceed independently from, and at times at cross-purposes with, the interests of certain states, even constituent states.

United Nations General Assembly resolutions, technically just recommendations, can constitute soft law. The United Nations General Assembly has adopted a number of resolutions pertaining to environmental matters. One of the more celebrated is the United Nations General Assembly Resolution on Development and Environment, which 'recognize[d] that no environmental policy should adversely affect the present or future development possibilities of the developing countries' (GA Res. 26/2849, 1972). ${ }^{7}$ Another is the World Charter for Nature and the United Nations General Assembly Resolution on the Protection of the Global Climate (GA Res. 43/53, 1988), recognizing climate change as a common concern of mankind. Following the Rio+20 Summit, the United Nations General Assembly Resolution 'The future we want' renews political commitment to 'sustainable development and to ensuring the promotion of an economically, socially and environmentally sustainable future for our planet and for present 
and future generations' (GA Res. 66/288, 2012). One of the latest contributions includes the United Nations General Assembly Resolution 'Transforming our world: the 2030 Agenda for Sustainable Development' (GA Res. 70/1, 2015), adopted by world leaders at a historic UN Summit. The 17 Sustainable Development Goals (SDGs) of the 2030 Agenda officially came into force on 1 January 2016.

The General Assembly can also be involved as an actor on the stage of international environmental law more indirectly. For example, the General Assembly established the World Commission on Environment and Development, better known as the Brundtland Commission after its Chairperson, former Norwegian Prime Minister Gro Harlem Brundtland, which in 1987 released a watershed report, entitled Our Common Future, which mainstreamed the notion of sustainable development. The United Nations General Assembly facilitated the 1972 United Nations Conference on the Human Environment (Stockholm Conference) and the 1992 United Nations Conference on Environment and Development (the Rio Conference or Earth Summit). These conferences served as pivotal gatherings in the development of international environmental law and also as points of inflection in international institutional law insofar as they saw the establishment of the United Nations Environmental Programme (UNEP) and the Commission on Sustainable Development (CSD) respectively. Soft law and hard law documents emerged from these gatherings.

The Security Council, which has primary responsibility for the maintenance of international peace and security, has been less active in environmental matters. It did create the United Nations Compensation Commission (UNCC), whose goal is compensation for the illegal activities of Iraq during its occupation of Kuwait, including compensation for the deliberate burning of Kuwaiti oil wells and spilling of oil into the Persian Gulf. Should climate change increasingly become associated with international peace and security, the Security Council may begin to take a more active role in this area as well.

A variety of specialized international organizations also are key actors in the process of international law-making. ${ }^{8}$ Autonomous agencies include the Food and Agriculture Organization (FAO), the World Health Organization (WHO) and the International Maritime Organization (IMO). International financial organizations, such as the World Bank and International Monetary Fund, play a crucial role. The United Nations Educational, Scientific, and Cultural Organization (UNESCO) coordinated the negotiation of the 1972 Convention Concerning the Protection of the World Cultural and Natural Heritage.

The United Nations also has developed programmes or agencies that, although not separate international organizations, serve an institutional function in initiating action among states and pre-existing international organizations. Examples include the UNEP, ${ }^{9}$ the United Nations Development Programme (UNDP),${ }^{10}$ and the CSD. ${ }^{11}$ UNEP and the CSD report to the General Assembly through the Economic and Social Council (ECOSOC). UNEP, based in Nairobi, has been very active in facilitating multilateral environmental agreements and in setting non-binding guidelines. As regards non-binding guidelines, UNEP developed various soft law documents, such as: (i) the Montreal Guidelines for the Protection of the Marine Environment against Pollution from Land-Based Activities, 1985; (ii) the Cairo Guidelines and Principles for the Environmentally Sound Management of Hazardous Wastes, 1987; and (iii) the London Guidelines for the Exchange of Information on Chemicals in International Trade, 1989. Hunter, Salzman and Zaelke identify it as 'the primary UN organ with general authority over environmental issues' (Hunter, Salzman and Zaelke, 2007: 170) and note that 'more than 40 multilateral environmental treaties have been negotiated under UNEP's guidance ...' 
(Hunter, Salzman and Zaelke, 2007: 224). UNEP is also an implementing agency of the Global Environmental Facility (GEF), a funding organization based in Washington DC specifically tailored to environmental issues. The GEF serves as the financial mechanism for four MEAs: the Convention on Biological Diversity (CBD), the Framework Convention on Climate Change (FCCC), the Convention to Combat Desertification (CCD), and the Stockholm Convention on Persistent Organic Pollutants. ${ }^{12}$ The FCCC is one of three intrinsically interlinked conventions adopted at the Rio Earth Summit in 1992. With the 197 ratifying countries, the FCCC has near-universal membership. The CBD currently has 196 state parties with the 2018 Conference of the Parties being held at the UN Biodiversity Conference in Egypt. The CCD has 195 state parties. The 2030 Agenda for Sustainable Development, mentioned above, refers to the need to integrate the SDGs into (the implementation of) this third Convention. It specifically invokes SDG 15 and related target 15.3: 'to combat desertification, restore degraded land and soil, including land affected by desertification, drought and floods, and strive to achieve a land degradation-neutral world' (Conference of the Parties, China, 2017). The CSD, based in New York, serves as a forum for discussion among state representatives on topics related to the integration of the environment and development. Other United Nations bodies also are involved in treaty development. For example, the Convention on Long-Range Transboundary Air Pollution was negotiated under the auspices of a regional body, namely the UN Economic Commission for Europe.

Even organizations far removed from the environmental sphere, such as the World Trade Organization (WTO), affect international environmental law. WTO dispute resolution entities have pronounced upon the relationship between free trade and domestic measures undertaken in pursuit of environmental protection. Regional organizations, such as the North American Commission on Environmental Cooperation, also help define the content of international environmental law. Investment dispute resolution arbitration under Chapter 11 of the North American Free Trade Agreement has informed the question whether environmental regulatory measures taken at the national level can amount to an impermissible expropriation.

In sum, a diffuse and fragmented number of international and intergovernmental organizations serve as actors in international environmental law. Unlike the International Labour Organization (ILO), there is no centralized world environmental agency. Although a proliferation of institutions may expand the scope of legalization, it may also give rise to inter-institutional competition, 'turf wars' on areas of shared or concurrent governance, diffuse responsibilities, contradictory jurisprudence and rule-making, and disutilities of scale. Unsurprisingly, some scholars have called for the creation of such an organization; this would have to be entirely new in design insofar as UNEP does not currently have the institutional mandate to serve as such (Palmer, 1992: 261; Charnovitz, 2002: 324-6). ${ }^{13}$

\subsubsection{State Administrative Agencies and Courts, Substatal Governments, Subnational Regions and Supranational Entities}

Although states are formal actors in international law, subnational and supranational entities may also play an important law-making role. In fact, in various states, the protection of the environment is one of the areas that may be subject to concurrent competences (e.g. in Germany). The interplay between national and subnational levels of government is reflected, inter alia, in the 2005 Organisation for Economic Co-operation and Development (OECD) Guiding Principles for Regulatory Quality and Performance, which are relevant to all states 
'whether they are federations, unitary states or somewhere in between' (OECD, 2010). In federated states, subnational governments may legislate on environmental matters within their own jurisdiction and, in that process, influence local norms which, in turn, affect attitudes toward transnational environmental regulation. By way of example, several US states have gone much further than the federal government in terms of regulating greenhouse gas emissions. Moreover, subnational governments may dispatch consular representatives to foreign countries, and even maintain missions abroad. Canadian provinces have done so.

Obversely, supranational entities may play important administrative, regulatory, and diplomatic roles in the formulation of international environmental policy. Undoubtedly, the most influential supranational entity in matters of international environmental law is the European Union (EU). Its administrative, diplomatic, and juridical apparatus have made it a trendsetter in matters of international environmental law-making. Indeed, EU actors have established an impressive environmental policy. For example, in 2017 the EU adopted its long- awaited Conflict Minerals Regulation, which will come into force across the EU in 2021. The Regulation aims to help stem the trade in four minerals: tin, tantalum, tungsten and gold (3TG) as these minerals sometimes finance armed conflicts or forced labour, and are used during mining activities. EU importers of 3TG from high-risk areas will have to comply with a mandatory due diligence obligation, conducted according to the OECD Due Diligence Guidelines.

Yet, the effective implementation of environmental policy, which largely depends on actors on the ground, has often been disappointing. In that respect, it is worthwhile to mention that subnational regions may feature formal and informal determinants that differ from national determinants.

Another European body, the European Court of Human Rights (ECtHR), linked environmental protection to the right to privacy in its judgment in Lopez Ostra v. Spain, holding that 'severe environmental pollution may affect individuals' well-being and prevent them from enjoying their homes in such a way as to affect their private and family life adversely' (Lopez Ostra v. Spain, 1994: 295). ${ }^{14}$ Although international human rights law and environmental law were traditionally treated as separate legal regimes, mutual links are being increasingly recognized. Human rights laws and courts can therefore be viewed as an additional avenue to challenge environmental violations (Baker McKenzie, 2017: 148-9). As regards the applicability of the European Convention on Human Rights (ECHR) in context of the right to a healthy environment, the ECtHR explained that:

Even though the European Convention on Human Rights does not enshrine any right to a healthy environment as such, the European Court of Human Rights has been called upon to develop its case-law in environmental matters on account of the fact that the exercise of certain Convention rights may be undermined by the existence of harm to the environment and exposure to environmental risks. (ECtHR Factsheet, 2018: 1)

In particular, the ECtHR linked environmental concerns with Article 2 (right to life) and Article 8 (right to respect for private and family life). In Öneryildiz v. Turkey, the ECtHR emphasized a positive obligation on states to protect the right to life from dangerous activities, such as nuclear tests or the operation of chemical factories with toxic emissions, whether carried out by public authorities or by private companies (Öneryildiz v. Turkey, 2004). In Tătar v. Romania, the ECtHR held that there had been a violation of the right to respect for private and family life in that 'the Romanian authorities had failed in their duty to assess ... the risks that the activity of the company operating the mine might entail, and to take suitable 
measures in order to protect the rights of those concerned to respect for their private lives and homes, and more generally their right to enjoy a healthy and protected environment' (Tătar v. Romania, Press Release, 2009: 3). In the context of businesses, the ECtHR in Hatton and Others $v$. United Kingdom stated that 'the State's responsibility in environmental cases may also arise from a failure to regulate private industry in a manner securing proper respect for the rights enshrined in ... the Convention' (Hatton and Others v. United Kingdom, 2003: 119). The applicants in this case alleged that government policies on night flights at Heathrow Airport violated their rights under Article 8, and that they were denied an effective domestic remedy contrary to Article 13 (Hatton and Others v. United Kingdom, 2003: 3). In this context, it should be noted that the ECtHR over time has adopted a more restrictive view on the application of Article 8 to environmental cases. The ECtHR's case law puts emphasis on procedural protection, which means that 'the decision-making process leading to activities that have an adverse effect on the environment, should involve appropriate facts and studies in order to predict this effect and strike a fair balance between the conflicting interests involved' (Leijten, 2019). This procedural approach to the margin of appreciation was also applied in the Hatton case, where the Court stated that 'national authorities are better placed to ... evaluate local needs and conditions' (Hatton and Others v. United Kingdom, 2003: 88 and 128). Similarly, the ECtHR in Fadeyeva v. Russia stated that 'in today's society the protection of the environment is an increasingly important consideration', but at the same time emphasized that the issues involved are so complex that the Court's task remains primarily a subsidiary one (Fadeyeva v. Russia, 2005: 103; Leijten, 2019). The ECtHR made clear that 'complaints relating to environmental nuisances have to show, firstly, that there was an actual interference with the applicant's private sphere, and secondly, that a level of severity was attained' (Fadeyeva v. Russia, 2005: 70). In other words, the focus is mainly on cases involving severe situations, where it is possible to 'determine whether the State has discharged its positive obligations - in light of the available (scientific) knowledge and given what eventually occurred - or failed to provide the necessary protection' (Leijten, 2019).

Most recent, and still pending, cases relate to the polluting emissions from the Taranto Ilva steel plant in Italy. The applicants allege that the Italian authorities failed to take the necessary measures to safeguard the environment and the health of persons (Locascia and Others v. Italy, Application communicated to the Italian government in 2013 and Cordella and Others v. Italy and Ambrogi Melle and Others v. Italy, Applications communicated to the Italian government in 2016). The ECtHR put questions to the parties under Article 2 (right to life), Article 8 (right to respect for private and family life) and Article 13 (right to an effective remedy) (ECtHR Factsheet, 2018: 2).

The African Commission on Human Rights and the Inter-American Court of Human Rights have also issued judgments and recommendations regarding the interface between human rights and environmental policy.

Violations of environmental law can indeed be conceptualized in various ways. Climate change litigation, for example, can be pursued through suits against governments (human rights framework, access to information, protection of biodiversity and ecosystems, environmental assessment or public trust) or corporations and individuals. As Docherty and Giannini put it, 'International approaches to minimizing its impacts should build on all applicable and effective legal frameworks that are available' (Docherty and Giannini, 2012).

The Inuit people tried to raise human rights concerns related to climate change, which affects both them and 'their' environment. In 2005, the Inuit Circumpolar Council submitted, 
on behalf of all Inuit of the Arctic regions of the United States and Canada, a petition to the Inter-American Commission on Human Rights. The petition claimed that the United States violates obligations to reduce greenhouse gas emissions, which in turn violates the rights of the Inuit people. In other words, the petitioners submitted that the effects of global warming constitute violations of Inuit human rights, for which the United States is responsible. The reference has been made, inter alia, to the right to the preservation of health, the right to life, physical protection and security (Petition to the Inter-American Commission on Human Rights, 2005: 74-95). It was further asserted that human rights obligations should be interpreted in the context of relevant international norms and principles, such as the principle of sustainable development, obligations under the FCCC and the Kyoto Protocol, and the obligation to avoid transboundary harm (Petition to the Inter-American Commission on Human Rights, 2005: 97-101). Although the Inter-American Commission rejected the Inuit petition, it offered one of the first linkages between climate change and human rights. Years later, this linkage was recognized in the Paris Agreement, which includes an explicit reference to human rights, and thus confirms the applicability of human rights obligations in the context of global warming (Duyck, 2015). Indeed, the adoption of the Paris Agreement has been followed by 'a burgeoning strand of climate change litigation' (Savaresi, Cismas and Hartmann, 2017). There are cases testing the boundaries of the law being heard in different jurisdictions and legal frameworks (Climate Change Litigation Databases, Sabin Center for Climate Change Law, Columbia Law School). Another petition, this time submitted by the Arctic Athabaskan Council, was filed with the Inter-American Commission on Human Rights in 2013. The petition seeks relief from violations of the rights of Arctic Athabaskan Peoples resulting from rapid Arctic warming and melting caused by emissions of black carbon by Canada. The case has not been decided yet.

One of the most recent and bold efforts in context of human rights violations associated with the impacts of climate change is a petition submitted by Greenpeace Southeast Asia, Filipino human rights groups and citizens to the Commission on Human Rights of the Philippines (CHR) in 2016. The CHR, as opposed to the Inter-American Commission in the Inuit case, asserted its jurisdiction to investigate the petition. This time, however, not states but corporations are under examination. The $\mathrm{CHR}$ is going 'to examine the possible contribution of carbon majors on climate change and its effects on the human rights of the Filipinos' (Republic of the Philippines Commission on Human Rights, Press Release, 2017). The CHR is requested to investigate 'the responsibility of 47 oil, gas, coal, and cement companies for human rights violations or threats thereof resulting from the impacts of climate change' (Savaresi, Cismas and Hartmann, 2017). Fact-finding missions and public hearings are scheduled for 2018, both in the Philippines and abroad. The CHR is also mandated to monitor compliance by the Philippines with its international obligations, including the Paris Agreement, the Kyoto Protocol, the International Covenant on Civil and Political Rights, and the International Covenant on Economic, Social, and Cultural Rights.

National courts in the US also play a key role. For example, the US Supreme Court in Massachusetts v. EPA ruled that the US Environmental Protection Agency has the authority to regulate greenhouse gas emissions. ${ }^{15}$ High courts in India have delivered several important judgments on the interface between constitutional principles and environmental policy in which principles of international environmental law, including the precautionary principle, have been invoked (see Vellore Citizens Welfare Reform v. Union of India, 1996: 2715; Razzaque, 2002). ${ }^{16}$ By invoking these principles and applying them, the Indian courts serve as 
dynamic participants in terms of importing these principles, and then also exporting them by augmenting their viability.

\subsubsection{Treaty Secretariats, Subsidiary Bodies and Conferences of the Parties}

Many MEAs pursue what has been called a 'framework approach'. This approach begins with a treaty document - agreed to by states - that identifies a general problem, the need to do something about it, and a procedure for subsequent discussions. The framework thereby is set. With agreement on the general framework now secured, many of the details regarding achieving targets, enforcing the treaty, and absorbing new developments and technologies are delegated to treaty bodies. ${ }^{17}$ Examples of treaty bodies include conferences of the parties (COPs), treaty secretariats, and specialized expert subsidiary bodies (see FCCC, 1992: Articles 7-10). These bodies are established by treaties as permanent organs. They hum along on a daily basis or meet in regularly convened meetings.

The logic of the framework approach is as follows: instead of negotiating every detail up front, which can be deeply contentious, the treaty first obtains generalized buy-in from states and leaves the details to incremental processes of discussion and management that take place after the fact. The reputation and transaction costs of states' exiting from a treaty regime once they have committed to it are higher than not joining in the first place.

State parties meet regularly (yearly, for example) in COPs. COPs may negotiate protocols that further the implementation of the treaty (for example, the Montreal Protocol under the Vienna Convention for the Protection of the Ozone Layer). COPs may interpret provisions of the MEA or Protocol in question. This is the case under the Montreal Protocol on Substances that Deplete the Ozone Layer (Article 10(1)). ${ }^{18}$ In 2016, the Kigali Amendment to the Montreal Protocol on Substances that Deplete the Ozone Layer was adopted. While being usually overshadowed by the 2015 United Nations Climate Change Conference in Paris (COP21), environmental experts note that the Kigali Amendment could be 'the single largest real contribution the world has made so far' relating to keeping the global temperature rise 'well below' 2 degrees Celsius, a target agreed at COP21 (UN Environment, Africa Office, 2016). The Kigali Amendment mandates countries to phase down the production and usage of hydrofluorocarbons (HFCs), which are powerful greenhouse gases that can be much more 'potent than carbon dioxide in contributing to climate change' (UN Environment, Africa Office, 2016).

One of the most important COPs in recent years was the previously mentioned COP21, with an equally important outcome - the Paris Agreement under the FCCC. The Paris Agreement contains both hard and soft law norms, while the boundaries between the two are often blurred. On the one hand, soft law norms may be more flexible and may allow for a wider participation of states in the Paris Agreement. On the other hand, hard law norms are considered more effective, as without a strong political will to change behaviour, reduction in greenhouse gas emissions will prove very difficult (Lawrence and Wong, 2017).

The Paris Agreement requires all state parties to put forward their best efforts through 'nationally determined contributions' (NDCs). In order to strengthen these efforts in the years ahead, all state parties are required to report regularly on their emissions and on their implementation efforts. The Paris Agreement combines a bottom-up approach including NDCs with a top-down approach including rules on transparency and review. This structure differs from the top-down approach adopted by the Kyoto Protocol, which 'sets out legally binding emis- 
sion reduction targets', while the requirement to submit mitigation-related NDCs in the Paris Agreement seems more problematic as 'mitigation targets set out in the NDCs are not legally binding' (Kohli, 2015). While it is recognized that MEAs 'may set out the basic framework in respect of global environmental matters', there is a need for 'continuous interaction of member States to provide guidance on ... the implementation of the MEA in a way that responds to the environmental challenge it seeks to address' (Camenzuli, 2007). With regard to the law-making capacity of COPs to develop MEAs, many issues remain unsettled and unclear (Churchill and Ulfstein, 2000), including the normativity of COPs' decisions (Merkouris, 2017). More consideration should be given to 'the legal personality of COPs, in particular, whether the exercise of their law making powers (if any) are properly conceptualized within the law of treaties and/or within international institutional law. This has in turn given rise to questions regarding the validity and legally binding nature of COP made "law" (Camenzuli, 2007). COPs may also implement soft settlement of disputes through non-compliance mechanisms. Non-compliance procedures have been adopted, for example, by the parties to the Montreal Protocol and the Basel Convention. In addition to a non-compliance procedure, Article 18 of the Kyoto Protocol establishes a 'multilateral consultative process'.

Some argue that it is the context, rather than the text, which has brought the biggest change from Rio in 1992 to Paris in 2015 (Jacquet and Jamieson, 2016). The Paris Agreement acknowledges that climate change is a common concern of humankind, and the challenges connected with climate change are thus increasingly perceived as much broader issues related to 'poverty reduction, peace, human rights, and even human identity' (Jacquet and Jamieson, 2016). Rwanda's Minister of Natural Resources Biruta, for example, noted that 'Africa is a continent that is deeply vulnerable to climate change. We are witnessing disastrous droughts - our people are losing lives. We need to address climate change if we are to address poverty' (UN Environment, Africa Office, 2016). Back in Paris, 196 state parties were joined in their commitments by a wide range of actors including intergovernmental and non-governmental organizations, mayors, governors, and business and civil society representatives. Specific actors and their actions include the Secretary-General of the UN (New York City's People's Climate March), the World Bank (commitment to bring to an end to financing for coal power), the Breakthrough Energy Coalition (commitment to invest US\$2 billion in renewable energy research) and Pope Francis' call to action through his message 'Show Mercy to our Common Home', which states that 'governments are obliged to honor the climate commitments they made ... It is up to citizens to insist that this happen, and indeed to advocate for even more ambitious goals' (Global Catholic Climate Movement, 2017).

There is no doubt that the Paris Agreement constitutes a significant step in combating climate change. Yet, we should not overlook the fact that the US, China and India are responsible for almost half of carbon emissions worldwide (Biello, 2014). These states have a critical role to play in action against global climate change, 'one of the greatest threats facing humanity' (US-China Joint Announcement on Climate Change, 2014). In other words, if anything undermines cooperation between these states, it undermines the Paris Agreement too.

The 2016 UN Climate Change Conference (COP22) took place in Morocco. It was the first meeting of the state parties since the Paris Agreement came into force. While COP21 in Paris was about a high-level negotiation that established broad strategies for mitigating greenhouse gas emissions, COP22 in Marrakesh focused on establishing a practical plan. It addressed, for example, how developed countries will concretely support countries 'on the front lines of a rapidly changing environment' (Hermann, 2016). The Nordic Pavilion at COP22 offered 
some examples found in the Arctic. Arctic Day shared the science behind monitoring climate change in the circumpolar north, as well as actions taken by Nordic Arctic communities in order to limit their emissions and adapt to new challenges (Hermann, 2016). The 2017 UN Climate Change Conference (COP23), which took place in Bonn in 2017, then hosted the Arctic Council event 'The global implications of a rapidly-changing Arctic'.

The Arctic is actually an increasingly important region faced with major challenges. Some authors claim that the Arctic is in the centre of issues that will 'challenge and define our world in the 21st century, including energy security, the struggle for natural resources, climate change, the return of great power competition, and the remaking of global trade patterns' (Emmerson, 2010).

One of the direct effects of climate change is warming of the Arctic, which is happening more than twice as fast as the rest of the planet. As a result 'An ice-free ocean will absorb more heat and accelerate global warming, while the consequences of warmer seas for the ecosystem and food chain will affect humans far below the Arctic region' (Center for International Climate Research, undated). The Arctic is undoubtedly experiencing transformative change. The challenges that climate change poses in the Arctic affect different sectors - including environmental, economic, political, military, legal and societal sectors. At the same time, climate change in the Arctic creates opportunities, as well as new environmental risks, connected with increased activity in the shipping, petroleum, mining and fishing industries, and will be critical for future economic and demographic development in the region. In this context, what does sustainable development mean in and for the Arctic?

The Arctic meltdown may increasingly have an impact also on territorial disputes in the Arctic (e.g. the issue of the sovereign claims of Denmark and Canada over Hans Island) or the sovereign claims of Canada, Denmark, Norway, the United States and the Russian Federation over the delimitation of maritime spaces under UNCLOS, especially with regard to their respective continental shelves beyond 200 nautical miles (Article 76). A multitude of other issues surface, such as geopolitical and security challenges and adaptation of individual Arctic states' armed forces to climate change. The Arctic is defined by change that goes beyond a physical transition such as an ongoing meltdown. Dynamism and evolution are reflected also in the way we approach the Arctic through international law, politics and policy. The legal regime of the Arctic is based on the fragmented international public law (both hard law and soft law mechanisms) and domestic law. These regimes and specific rules intersect and interact, making Arctic governance very complex and multifaceted (Schönfeldt, 2017).

Treaty management through COPs often overlaps with the creation of a treaty or convention secretariat, which remains 'responsible for the day-to-day operations of the convention' (Hunter, Salzman and Zaelke, 2007: 250). Ordinarily, secretariats are thinly staffed and, accordingly, rely on cooperation from state parties and their good faith in terms of self-reporting information and self-assessing compliance. In some cases, for example, the Vienna Convention for the Protection of the Ozone Layer (and Montreal Protocol) and the Convention on International Trade in Endangered Species, UNEP (in Nairobi and Geneva respectively) serves as the treaty secretariat. The CBD secretariat, also tied to UNEP, is located in Montreal. The IMO serves as the secretariat for the 1972 Convention on the Prevention of Marine Pollution by Dumping of Wastes and Other Matter (London Convention on Ocean Dumping) and also for the International Convention for the Prevention of Pollution from Ships (1973), as modified by the Protocol of 1978 relating thereto (MARPOL 73/78). Both of these conventions are kept up to date by the use of a tacit consent/opt-out procedure. The 
Convention to Combat Desertification and the FCCC secretariats are housed together in Bonn, Germany. Secretariats manage many activities, as is evident simply by perusing the extremely sophisticated websites of major international environmental conventions. ${ }^{19}$ Subsidiary bodies address technical and scientific issues that may arise in terms of treaty implementation. ${ }^{20}$

In sum, treaty secretariats, COPs, and subsidiary bodies have become pertinent actors in the formulation of international environmental law. As Ulfstein notes, they 'have important roles in developing the substantive commitments of MEA parties' (Ulfstein, Chapter 4 in this volume). They develop expertise, foster scientific know-how, survey compliance, promote cooperation, determine funding, and push administrative rule-making as a phenomenon in international environmental law. They help ensure that the treaty is not static, but a robust and ongoing process of law-making, normative discussion and agility. Accordingly, and regardless of whether they formally have international legal personality or whether they have such personality through implied powers (generally not the case), treaty bodies effectively serve as actors involved in making international environmental law.

To the extent, however, that the activities of treaty bodies become increasingly bureaucratized and institutionalized, questions of legitimacy and democratic deficit may arise (see Bodansky, 1999: 596). Furthermore, should treaty secretariats and COPs pursue their institutional mandates independently of the activities of other treaty secretariats and COPs, the result may be not only a fragmentation but even an undermining of the effectiveness of international environmental law. For example, if one way to protect the ozone layer is to introduce products without CFCs but which, in turn, contribute to global warming, the pursuit of institutional mandates under the Montreal Protocol may be at cross-purposes with the pursuit of climate change regulation. This proliferation phenomenon is similar to that noted previously with regard to international organizations concerned with the environment.

\subsubsection{Major International Conferences}

Three major international conferences on environmental matters have served as important points of inflection in the development of international environmental law. These events have social constructivist value in that they are generally preceded by years of planning and discussion, and public dissemination of information, receive extensive media coverage, and lead to the adoption of important instruments. Most of the adopted instruments were of a soft law nature, although - as detailed below - two major hard law treaties (the FCCC and CBD) were adopted at the 1992 Conference on Environment and Development.

- The Conference on the Human Environment, held in Stockholm in 1972: 113 countries, two of them represented by their Heads of State, attended. Three major outputs emerged from this gathering: (1) an Action Plan to protect the global environment, which identified environmental concerns that necessitated multilateral responses; (2) the Stockholm Declaration on the Human Environment, a watershed soft law document; and (3) the creation of UNEP.

- The Conference on Environment and Development (also called the Earth Summit), held in Rio de Janeiro in 1992: 178 states participated, 115 represented by Heads of State. Representatives of 1400 non-governmental organizations were present. This conference was much larger than that at Stockholm two decades earlier, and was a veritable media circus. Many conference objectives had previously been established by the United Nations 
General Assembly (GA Res. 44/228, 1989). Although free from the Cold War strains that had hampered prior international negotiations, new strains emerged at Rio, specifically the North/South divide, with the South focused on local environmental problems, economic growth, and intra-generational equity and the North on global problems and intergenerational equity. Also, among the nations of the North, Rio constituted a point of inflection where the United States began to become diplomatically isolated in matters of global environmental governance. Several outputs emerged from this Conference: (1) the Rio Declaration on Environment and Development; (2) the adoption of hard law instruments: the FCCC and CBD; (3) Agenda 21, a lengthy, 800-page 'blueprint' for sustainable development; (4) the CSD; and (5) agreement to forge ahead on developing treaties on the topic of desertification, straddling fish stocks, and land-based sources of marine pollution.

- The World Summit on Sustainable Development, held in Johannesburg in 2002: 100 Heads of State attended. The Summit was slightly different to its predecessors in that it was modelled on, and pushed, 'partnership initiatives' that more actively incorporated civil society and non-state private stakeholders. Outputs from this gathering were more modest: (1) the Johannesburg Declaration on Sustainable Development (a statement of political commitment, not a series of principles like the Rio and Stockholm Declarations, and hence of lower normative value within the context of soft law instruments); and (2) a Plan of Implementation.

- The UN Conference on Sustainable Development (also known as Rio+20), held in Rio de Janeiro in 2012: called for by the United Nations General Assembly (GA Res. 66/197, 2012). Outcome document A/CONF.216/16, includes 'The future we want'.

- The UN Sustainable Development Summit, held in New York in 2015: convened as a high-level plenary meeting of the United Nations General Assembly. Outcome document: A/RES/70/1, includes 'Transforming our world: the 2030 Agenda for Sustainable Development'.

\subsubsection{Non-Governmental Organizations (Non-State Actors) and Networked Expert Communities}

Non-governmental organizations are neither official subjects nor objects of international law. Accordingly, they are not actors in a formal sense. They are not state organs. Nor are they created by states. They are 'formed by individuals or private groups sharing a common objective' (Damrosch et al., 2001: 359). Non-governmental organizations range from Amnesty International to al-Qaeda. They may be specifically oriented towards legal/human rights issues (that is, Amnesty International) or cause changes in the law through their violence (that is, al-Qaeda).

Non-governmental organizations are particularly active in international environmental law-making. There are a number of organizations specifically geared to changing the law and/or raising awareness of under-regulated matters. Examples of such organizations include well-known environmental groups such as the Sierra Club, the Center for International Environmental Law, the European Environment Bureau and Greenpeace. In fact, there are thousands of environmental non-governmental organizations, an important number of which are involved in transnational issues. Newer environmental non-governmental organizations committed to legal reform have proliferated in the South, with exciting initiatives throughout Africa, Asia and South America. Global civil society, a phrase used to describe private 
non-governmental actors, constituted a key sector at the Rio Conference. The influence and composition of global civil society are inextricably linked to social media.

Although lacking in formal capacity to make law, non-governmental actors play dynamic roles in developing law. They can serve as coordinators: for example, the 1979 Convention on the Conservation of Migratory Species of Wild Animals resulted from negotiations by states organized by the International Union for the Conservation of Nature. In October 1992, Handicap International, Human Rights Watch, Medico International, the Mines Advisory Group, Physicians for Human Rights, and the Vietnam Veterans of America Foundation formed the International Campaign to Ban Landmines (ICBL). The ICBL reports that 1400 non-governmental actors in 90 countries galvanized the anti-landmines movement, ${ }^{21}$ culminating in 1997 in the Convention on the Prohibition of the Use, Stockpiling, Production and Transfer of Anti-Personnel Mines and on their Destruction (Ottawa Convention). Although not an environmental treaty per se, the Ottawa Convention promotes human rights and environmental security by prohibiting anti-personnel mines hidden in the natural environment. The Ottawa Convention entered into force in 1999.22 The ICBL, together with its former coordinator, Jody Williams, were honoured with the Nobel Peace Prize in 1997. Similarly, the Intergovernmental Panel on Climate Change (IPCC) and former US Vice President Al Gore were awarded the Nobel Peace Prize for their efforts to obtain and disseminate information about the climate challenge in 2007.

Moreover, non-governmental organizations are often consulted by state representatives and may even sit in on negotiations as part of state delegations for major international environmental conventions or amendments thereto. Non-governmental actors pushed the WHO and the United Nations General Assembly to request an advisory opinion from the ICJ on the question of the legality of nuclear weapons. The International Physicians for the Prevention of Nuclear War and the World Federation of Public Health Associations were influential in the World Health Assembly of the WHO. Ultimately, the ICJ found jurisdiction only over the General Assembly's request and, in 1996, issued its opinion that the use of nuclear weapons would be unlawful under international humanitarian law except in extreme cases of self-defence (Advisory Opinion on the Legality of the Threat or Use of Nuclear Weapons, 1996: 811). In the Shrimp/Turtle dispute before the WTO, discussed below in Section 1.3.4.1, amicus curiae briefs were submitted through the applicant, the United States. These briefs were prepared by non-governmental organizations, including the Sierra Club, the Center for International Environmental Law, the Philippine Ecological Network, the Worldwide Fund for Nature and the Foundation for International Environmental Law and Development.

International relations scholars have observed that 'networks' of expert and regulatory communities disseminate information among themselves, thereby contributing to transnational legalization (Zaring, 2005: 602 and fn 252; ${ }^{23}$ Slaughter, 2003: 1042-3). ${ }^{24}$ Other scholars have described these 'networks' as 'epistemic communities' (Haas, 1992: 3) ${ }^{25}$ Networks are not registered organizations like non-governmental organizations. Nonetheless, their lack of formality belies their great effect on international environmental law. Experts are ordinarily members of domestic bureaucracies, research institutions and universities, but become networked transnationally through shared interests and concerns, and work toward common goals.

In some cases, expert communities may link with treaty bodies through their contacts with subsidiary bodies. In other cases, expert communities may be invited by states or international organizations to share their knowledge, research, and opinions. The IPCC - a multinational 
scientific body organized under the auspices of United Nations agencies - and its Working Groups have provided critically influential reports regarding global warming. In Massachusetts v. United States Environmental Protection Agency, the majority of the United States Supreme Court relied upon the Working Group I Report (2001) of the IPCC to effectively take judicial notice of increases in carbon dioxide emissions in the atmosphere (Massachusetts v. EPA, 2007: 4). The majority also referenced the IPCC's 1990 work regarding the relationship between human activity and atmospheric concentrations of greenhouse gases (Massachusetts v. EPA, 2007: 5-6). ${ }^{26}$ This is but one of many examples where networked communities serve as transnational law-making actors; their reports become incorporated by national courts which, as explored in Section 1.3 of this chapter, constitute a subsidiary source of international law.

\subsubsection{Individuals and corporations}

Individuals are subjects of international law only in the most limited sense. For example, international criminal law permits the prosecution and punishment of individuals for genocide, crimes against humanity and war crimes. There have been very few prosecutions under international criminal law for devastation of the environment. There have been even fewer convictions. The International Military Tribunal at Nuremberg convicted German General Jodl for war crimes as a result of scorched earth tactics in Norway and Russia (Heller and Lawrence, 2007). Nazi General Rendulic was acquitted in one of the subsequent proceedings for the wanton destruction forces under his command inflicted upon retreat in Norway. The Rome Statute of the International Criminal Court (ICC), which entered into force in 1998, criminalizes

Intentionally launching an attack in the knowledge that such attack will cause incidental loss of life or injury to civilians or damage to the non-human environment which would be clearly excessive in relation to the concrete and direct overall military advantage anticipated. (Rome Statute of the ICC, 1998: Article 8(2)(b)(iv))

The wording used in Article 8(2)(b)(iv) was adopted from the 1977 United Nations Convention on the Prohibition of Military or any other Hostile Use of Environmental Modification Techniques (ENMOD). In addition to this war crimes definition, the Office of the Prosecutor (OTP) of the ICC stated that it would seek to cooperate and provide assistance to state parties regarding conduct which constitutes 'a serious crime under national law, such as the illegal exploitation of natural resources, land grabbing or the destruction of the environment' (Fatou Bensouda, Policy Paper on Case Selection and Prioritisation, ICC, 2016: 3). In this context, the OTP will particularly focus on prosecuting crimes under the Rome Statute that are committed 'by means of, or that result in, inter alia, the destruction of the environment, the illegal exploitation of natural resources or the illegal dispossession of land' (ICC, 2016: 14).

An explicit reference to land-grabbing is significant since this worldwide practice became increasingly common, as evidenced, for example, in Cambodia. A member of the ICC working group, Reinhold Gallmetzer, stated that 'forcible transfer [of people] can already be a crime against humanity, so if it is committed by land-grabbing - whether as a result or a precursor - it can be included' (Maton, 2016). It should be noted that this inclusion will not 'make land-grabbing per se a crime, but mass forcible evictions that results from land-grabbing may end up being tried as a crime against humanity', said Richard J. Rogers of the public-interest law firm Global Diligence. Since land-grabbing often results in deforestation, addressing 
this phenomenon is especially helpful in tackling some of the causes of climate change. As a victims' legal representative, Rogers has filed a communication at the ICC alleging that both the government and business representatives subjected civilians to forcible transfer of populations, persecution, murder and 'other inhumane acts' (Loughlin, 2016). With regard to mass land-grabbing specifically, Rogers contends that 'in the past 14 years, an estimated 770,000 people ( $6 \%$ of the country's population) have been adversely affected by land grabbing in Cambodia, with over 145,000 people forcibly transferred from the capital, Phnom Penh, alone' (International Federation for Human Rights, 2014). Clearly, these are not some isolated acts of forcible transfer, but destructive practices reaching shocking levels. Whether the ICC will act, in fact, in accordance with its Policy Paper remains to be seen. William Schabas has cautioned that the significance of the Policy Paper is being 'greatly exaggerated' and any investigation into the Cambodian case is unlikely. He further suggests that hoping for a big shift would lead to disappointment (Maza, 2016). That may as well be. However, it may as well be that the ICC will at least work more closely with state parties in cases involving environmental damage, including land-grabbing. These cases could be prosecuted under national law, as indicated in the Policy Paper (ICC, 2016: 3), with the ICC's expertise available in order to aid the domestic investigations. Such shift in itself might represent an important new strategy for the ICC.

Looking at the more positive side of human nature, individuals can play a catalytic role as actors in formulating international law in ways similar to non-governmental actors. They can inspire others through their charisma, lead diplomatic gatherings, and inculcate values of stewardship for the environment. The effect of individuals such as former US Vice-President Al Gore (who made the documentary An Inconvenient Truth), Maurice Strong (who led the Stockholm and Rio Conferences), Rachel Carson (whose book Silent Spring served as a spark for environmentalism), and Dr Mostafa Tolba (former UNEP Executive Director and central to the ozone negotiations) should not be underestimated. When moving from formulating international law to protecting our environment, we equally should not underestimate the roles of environmental actors on the ground as the effective implementation of environmental policy largely depends on 'environmental agencies, employees, and contractors ... . Just as we need police officers, fire-fighters, and other first responders to protect the public safety, we need environmental responders to protect our environment' (Villa, 2019: 333).

Like individuals, corporations have a nationality. This often, though not exclusively, is the state in which they are incorporated (Case Concerning the Barcelona Traction, Light and Power Company, 1970: 42). Also, like individuals, corporations 'must in most instances rely on the protection of the government of which they are nationals and do not have access to international legal proceedings to protect their rights' (Damrosch et al., 2001: 421). Corporations also de facto play a part as actors in international environmental law. Corporate actors, and the non-governmental associations that represent them, have in some cases promulgated reports or created codes of conduct that bear upon environmental impacts (Anton et al., 2007: 572-88). Corporate actors may adopt international production standards for environmental management systems, for example, those established by the International Organization for Standardization (another non-governmental organization based in Geneva), ${ }^{27}$ which may promote sustainable development. Certain non-governmental organizations representing corporate interests may lobby for more circumspect environmental regulation. Others may seek to synergize regulation with areas in which certain industries may have carved out environmentally friendly technology. And yet others, which may represent corporations that specialize in environmen- 
tally friendly technologies, may promote more vigorous regulation. Corporations, after all, are heterogeneous.

Looking at the darker side of corporate's activities, much of the discussion revolves around corporate-related human rights abuses (Kamminga, 1999; Alston, 2005; Murphy, 2005; Wouters and Chanet, 2008). Attempts to bring in the private sector are ever increasing, although the actors primarily and directly responsible for human rights violations remain, of course, states, the original and traditional subjects of international law. In other words, human rights law does not apply directly between corporations and victims of corporate-related human rights violations. Human rights law, as Goisis put it, 'imposes duties on states to protect human rights and the environment against corporate abuses' (Goisis, 2017: 22). States have a role and responsibility 'to regulate and control corporate actors to prevent human rights and environmental violations, and to provide effective enforcement mechanisms that is, to investigate, punish, and redress such violations when they occur' (Goisis, 2017: 22). However, corporations, especially multinational enterprises (MNEs), are alleged to impact the full spectrum of human rights and there are various soft law documents addressing responsible business conduct wherever they operate (e.g. 2011 UN Guiding Principles on Business and Human Rights or 1976 OECD Guidelines for Multinational Enterprises, last updated in 2011). Despite the fact that human rights violations occur in different business contexts worldwide, prosecution of corporate actors that commit or are complicit in the commission of crimes linked to human rights abuses rarely follows:

[S]ystems of accountability built by regulators and implemented by law enforcement have not kept pace with the globalisation of corporate crimes. Particularly in the area of human rights and wrongdoing across borders, gaps exist where investigators, prosecutors and State policy-makers have failed to challenge corporate actors when they engage in crimes. (The Corporate Crimes Principles, 2016: i)

The Principles define corporate crime as 'illegal conduct that is linked to a human rights abuse, including conduct that should be criminalised in order to meet requirements under international law even if the State has failed to do so' (The Corporate Crimes Principles, 2016: i). Reasons for this failure may be several and the primary responsibility to fill this accountability gap is clearly on the state. But the Principles call also on law enforcement authorities to apply the full range of existing laws and to prosecute corporate crimes to the maximum extent possible. When approached broadly, corporate crimes may include human rights abuses that should be criminalised (e.g. forced labour, torture or trafficking in human beings), as well as 'conduct which may result in, or contribute to, human rights abuses' (The Corporate Crimes Principles, 2016: ii). In the context of environmental protection, the following offences can be included: toxic waste dumping (impacting on the right to life, health or water); pollution of air, land or water (impacting on the right to work, water or health) or extortion (armed groups controlling mine sites). The former member of Kenya's High Court, Ng'ang'a Thiong'o, addressed the conflict between economic growth and environmental protection in Africa in the following expressive terms:

Our war in Africa is the struggle against poverty. It is the fight against HIV/AIDS. As long as we are fighting these, nothing else seems to count. Global warming and environmental degradation are being ignored. Instead, we increasingly open our markets to achieve competitiveness in the international market. China can dump whatever it likes inside our shores. In the name of economic growth and development, mines can be opened up and our forests destroyed. (Thiong'o, 2011: 179) 
Serious human rights violations and commission of crimes go, in many countries and situations, hand in hand with environmental degradation (as illustrated by the Anvil case below). For example, Bales argues that slavery or forced labour in various states usually coexists with large environmental destruction and as such not only destroys individuals and whole communities, but also poses a grave threat to the environment (Bales, 2016).

Several cases briefly demonstrate both the legal possibilities and challenges in redressing harm for corporate-related offences with a large negative impact on communities and the environment. In South Africa, the Regional Court of Ermelo in a 2012 decision convicted the mining company Golfview Mining (Pty) for breaching the National Environmental Management Act and the National Water Act, namely for connection with the illegal mining and pollution of a wetland (State v. Golfview Mining (Pty) Ltd). In 2014, still in South Africa, the managing director of a clay mining company was convicted of violating the National Environmental Management Act and sentenced to five years' imprisonment (State v. Blue Platinum Ventures Pty Ltd \& Maponya). Through its mining operations in Limpopo, the mining company Blue Platinum caused severe environmental damage, which harmed the local community, and failed to rehabilitate damage to the mining location. This decision marks the first time in South Africa that a director of a corporation has been found personally liable for an environmental offence related to mining (The Corporate Crimes Principles, 2016: 62).

Another case involving serious human rights abuses and commission of crimes is from the Democratic Republic of the Congo (DRC) where the exploitation of the DRC's mineral wealth featured importantly during armed conflicts. The case involves activities of Canadian/ Australian multinational Anvil Mining Ltd. In this case, all three states failed to exercise jurisdiction for the 2004 massacre of over 70 people in Kilwa (DRC). Finding no remedy in the DRC, survivors and families tried to pursue justice in Australia and Canada, where Anvil Mining had offices. All attempts to seek justice through criminal as well as civil courts have so far been unsuccessful (including an appeal to the Canadian Supreme Court).

In the end, the Institute for Human Rights and Development in Africa and others brought the complaint on behalf of the victims to the African Commission. In a ground-breaking decision, the African Commission held that the DRC violated the African Charter on Human and Peoples' Rights (torture, forced displacement, extrajudicial executions and other serious violations) and awarded the victims US\$2.5 million, the highest award granted by the African Commission so far. As regards the role of Anvil Mining, the African Commission stressed that extractive industry companies should at a minimum 'avoid engaging in actions that violate the rights of communities in their zones of operation. This includes not participating in, or supporting, violations of human and people's rights' (Communication 393/10, 2016: para. 101 of French original). It also urged the DRC government to launch a new criminal investigation (previous investigations resulted in an acquittal of three employees of Anvil Mining) and to 'take all due measures to prosecute and punish agents of the State and Anvil Mining Company staff' (Communication 393/10, 2016).

True, findings and recommendations of the African Commission are not formally binding and the case cannot be referred to an African Court of Human and Peoples' Rights (Court), since the DRC does not recognize the competence of the Court and did not ratify the Protocol on the Establishment of an African Court on Human and Peoples' Rights. This makes it difficult to enforce the decision. Nevertheless, there are various (in)formal ways to exert pressure on the DRC, including pressure from other African states, which are members of the African 
Commission, or from international donors, which financially support the African Commission and the African Union.

The last case to be mentioned is from Côte d'Ivoire. This case involved multinational commodities trader Trafigura and toxic waste dumped in and around the city of Abidjan in 2006. As a result of dumping, more than 100,000 people had to seek medical assistance, about 15 people died and extensive cleaning and decontamination were required (Amnesty International and Greenpeace, 2012: 51-8). Various jurisdictions initiated proceedings against Trafigura. Côte d'Ivoire authorities arrested two Trafigura executives and charged them with 'poisoning and breaches of public health and environmental laws' (Amnesty International and Greenpeace, 2012: 129). UK courts in 2006 dealt with a civil claim against Trafigura brought by 30,000 victims of the dumping (Yao Esaie Motto \& Others v. Trafigura Limited and Trafigura Beheer BV in the High Court of Justice). A settlement agreement was finally reached, under which Trafigura agreed to pay $£ 30$ million, with no admission of liability for the dumping (UK Claim, Agreed Final Joint Statement, 2006). At the time of writing, there are civil proceedings against Trafigura in Côte d'Ivoire and the Netherlands. The Trafigura case thus illustrates 'how a corporate crime case involving multiple jurisdictions can give law enforcement in relevant jurisdictions legal grounds to take action' (The Corporate Crimes Principles, 2016: 13).

\subsection{WHAT ARE THE SOURCES OF INTERNATIONAL ENVIRONMENTAL LAW?}

Article 38(1) of the ICJ Statute identifies the sources of international law as:

(a) international conventions, whether general or particular, establishing rules expressly recognized by the contesting states;

(b) international custom, as evidence of a general practice accepted as law;

(c) the general principles of law recognized by civilized nations;

(d) subject to the provisions of Article 59, ${ }^{28}$ judicial decisions and the teachings of the most highly qualified publicists of the various nations, as subsidiary means for the determination of rules of law.

Article 38(2) preserves ex aequo et bono as a source of international law. ${ }^{29}$

The corpus of international environmental law derives from each of these sources. Although Article 38(1)(a) refers to 'international conventions', what is contemplated by this source of law are 'international agreement[s] concluded between states in written form' (Vienna Convention on the Law of Treaties, 1969: Article 2(1)(a)). Accordingly, Article 38(1)(a) covers agreements regardless whether they are called conventions, treaties, pacts, protocols or covenants. In this section, we use the terms 'treaty' or 'MEA' (in the specific context of multilateral environmental treaties) as shorthand for this source of law.

'Soft law' also informs international environmental law. Soft law, to build on the definition provided earlier in this chapter, is law-like behaviour that falls outside the principal sources of law identified in Article 38(1) (these principal sources, in turn, can be referred to as 'hard law'). The principal sources identified in Article 38(1) - treaties, custom and general principles of law - are positivistic in that they are made by actors through consensual processes. As a general matter, once states consent, these sources of law become binding upon them. 
Publicists such as the International Law Commission (ILC) and judicial bodies such as the ICJ, as well as national courts, also play vital - albeit subsidiary - roles. Yet, decisions of both national and international courts may not be necessarily treated as 'mere' subsidiary means for the determination of rules of law in light of Article 38(1) (Uhlírová, 2013: 26). There is a considerable practical and doctrinal support that case law can serve as an evidence of opinio juris or amount to state practice. This text adopts such a proposition, thereby partly departing from the classic distinction between primary and secondary sources reflected in Article 38(1).

The taxonomy of principles that are influential in international environmental law-making includes a number of concepts that defy precise classification in the sources of law enumerated above. Nonetheless, these concepts - many of which derive from moral philosophy, natural law, environmental economics and ecology - also inform the law-making process. They remain influential despite not (yet) having risen to the level of international custom, or even to the level of general principles of law, or despite being referenced in treaties only in an imprecise, preambular or hortatory manner. This suggests that what exactly constitutes international environmental law, or what exactly has law-like influence, is porous, malleable and expansionary. Moreover, each of the principles of international environmental law is interconnected: at times mutually reinforcing, at times mutually contradictory.

All told, the process by which international environmental law is made is disaggregated, decentralized, ad hoc, amorphous, dynamic and largely consensus-based. There are close to 900 international instruments that pertain to international environmental regulation (Weiss, 1993: 679). Since Weiss completed her crucial work, the number of such instruments has substantially increased.

\subsubsection{Treaties}

Treaties are contracts among states. They are binding for those states that consent to them. Consent is articulated when states, after having negotiated and adopted the treaty, sign it and then ratify it domestically. In practice, it is at this juncture that a state becomes a party to the treaty. The Vienna Convention on the Law of Treaties addresses the definition, creation, interpretation, termination, and amendment of international treaties. ${ }^{30}$ International organizations also can be parties to treaties, though in practice this is infrequent. ${ }^{31}$ Individuals, non-governmental organizations and corporations cannot be parties to treaties. That said, they can be influential in setting the stage, and limiting the stage, for treaty negotiations among states. $^{32}$

Treaties (MEAs) are the major source of international environmental law. Moreover, although formally they govern only those states that consent to them, they can also constitute important evidence of customary international law and general principles of law.

Although the 1972 Stockholm Conference is, in general parlance, associated with the beginnings of international environmental law, a number of international environmental treaties trace back to the beginning of the 20th century. For example, a 1911 Convention was aimed at curbing the slaughter of northern fur seals. ${ }^{33}$ The post-Stockholm Conference era, however, has seen a veritable flurry of treaty-making activity.

Treaties can be bilateral (between two states) or multilateral (between more than two states). Multilateral treaties may be regional (between all states in a geographic region) ${ }^{34}$ or they may be truly global (between a large number of states located all over the world). Major MEAs can be divided into two groups: first generation and second generation. First-generation 
MEAs focus on issues such as air and water pollution, wildlife conservation and protection of vulnerable habitat. Pivotal first-generation treaties include MARPOL 73/78; the London Convention on the Prevention of Marine Pollution by Dumping of Wastes and Other Matter (1972); the Convention on International Trade in Endangered Species of Wild Fauna and Flora (CITES) (1973); and the Ramsar Convention on Wetlands (1971). Second-generation MEAs involve even more complex issues, which implicate economic behaviour and lifestyles at a multiplicity of levels. Pivotal second-generation treaties include the Vienna Convention for the Protection of the Ozone Layer (1985), and subsequent Protocols (in particular the Montreal Protocol (1987) and London Amendment thereto (1990)); the United Nations Framework Convention on Climate Change (FCCC) (1992) and the Kyoto Protocol (1997) including the Doha Amendment to the Kyoto Protocol (2012); the Convention on Biological Diversity (CBD) (1992); the Basel Convention on the Control of Transboundary Movements of Hazardous Wastes and their Disposal (1989); and the United Nations Convention to Combat Desertification (CCD) (1994). Another major MEA is the United Nations Convention on the Law of the Sea (UNCLOS) (1982) which, although not primarily concerned with environmental issues, addresses pollution and protection of the marine environment. On 3 June 2015, the United Nations General Assembly adopted a resolution in which it decided to develop an internationally legally binding instrument under UNCLOS on the conservation and sustainable use of marine biological diversity of areas beyond national jurisdiction (GA Res. 69/292, 2015).

Some of these first- and second-generation treaties set broad global norms. When a large majority of all states become parties to a global environmental treaty, it assumes what can be called quasi-constitutional status. It is not intended here to use the phrase 'quasi-constitutional status' in the sense of constitutions in domestic law, which may be ordinarily viewed as the highest source of law and which may be enforced through third-party courts/constabulary, but rather in the metaphysical sense of a deeply influential norm-creating and value-ordering document. Some of these quasi-constitutional treaties, and their numbers of parties, are as follows: CBD (196 parties); ${ }^{35}$ CITES (183 parties) $;{ }^{36}$ Basel Convention (186 parties); ${ }^{37}$ Vienna Convention for the Protection of the Ozone Layer (197 parties, the Montreal Protocol also has 197 parties and the London Amendment 197 parties); ${ }^{38}$ FCCC (197 parties, the Kyoto Protocol has 192 parties and the Doha Amendment to the Kyoto Protocol, adopted in Qatar in 2012, has 108 state parties); ${ }^{39}$ CCD (196 parties), ${ }^{40}$ Ramsar Convention (169 parties); ${ }^{41}$ UNCLOS (168 parties); ${ }^{42}$ MARPOL 73/78 (154 parties to Annex I/II, totalling 98.7 per cent of world shipping tonnage). ${ }^{43}$

International environmental treaties, as foreshadowed in Section 1.3.1 above, have innovated in terms of processes of law-making. Certain treaties invite COPs, treaty secretariats and subsidiary bodies to do much of the implementing work. Other treaties involve states initially to secure agreement on broad principles but, once the framework for such agreement exists, turn to institutional actors to undertake much of the hard work of implementation. Other treaties utilize formal mechanisms such as Protocols (FCCC), appendices (CITES), and annexes (MARPOL 73/78) to foster additional agreement, or finesse details, once the proverbial 'big picture' has been consented to. Another innovation is the tacit acceptance procedure. One example is the 1996 Protocol to the 1972 London Convention. This Protocol protects the marine environment by prohibiting dumping except for materials on an approved list. Amendments to the annexes enter into force no later than 100 days after their adoption. Amendments bind all parties except those parties that explicitly express their non-acceptance thereof. Hence, the reach of the law advances through tacit acceptance. 


\section{Research handbook on international environmental law}

An analysis of the effectiveness of treaties, assuredly, transcends simply adding up the numbers of parties. After all, many parties may agree, and therefore become bound, to a vague or generalized commitment. This does not ensure action towards resolving the problem at hand. Compliance does not guarantee effectiveness. A hard commitment in a soft law document may prove to be more effective than a soft commitment in a hard law document.

In addition to regulating the specific areas within their mandates, treaties give a voice to important principles of international environmental law. Examples include: common but differentiated responsibilities,${ }^{44}$ common concern of humankind, ${ }^{45}$ shared compact (see CBD, 1992: Article 20(4)) $)^{46}$ prior informed consent (Basel Convention, 1989: Articles 4(1)(c) and $6),{ }^{47}$ and public participation in environmental decision-making. ${ }^{48}$

Furthermore, treaties formally outside the field of international environmental law also affect the content of international environmental law. There has, to various degrees of success and frustration, been integration of environmental concerns in international trade instruments, international human rights instruments and international humanitarian law instruments.

\subsubsection{Custom}

Customary international law is defined as state practice followed out of a sense of legal obligation (opinio juris). It therefore has a behavioural component (empirically identifying regularities of state conduct) and an intent component (ascertaining whether those regularities are conducted with legality - as opposed to just morality, expedience or convenience - in mind).

Something can constitute customary international law in the absence of uniformity of state practice. The practice must be extensive, however, although there is no requirement that it be long-standing; and the practice must include states particularly affected by the purported custom. Examples of practice include state declarations, treaty ratifications, external communications, official statements, sanctions for breach of the purported custom and the actual conduct of state affairs.

Customary international law is binding on all states, even states that postdate the emergence of the custom, except for a state that persistently objects to a custom as it is emerging. That said, no state can object to a peremptory norm of international law (a jus cogens). Nor can any treaty violate a peremptory norm (Vienna Convention on the Law of Treaties, 1969: Article 53).

Doctrinal controversy persists regarding which elements of international environmental law are sourced in international custom. Potential candidates, whose claims to customary status have ripened to different degrees, include:

- the obligation not to cause environmental harm - although states are sovereign over their territory, a state is prohibited from acting within its territory in a way that causes environmental harm outside its territory (Stockholm Declaration, 1972: Principle 21; Rio Declaration, 1992: Principle 2) ${ }^{49}$

- the precautionary principle, which precludes lack of scientific certainty from postponing cost-effective measures to prevent environmental degradation; ${ }^{50}$

- the requirement to conduct an environmental impact assessment; ${ }^{51}$

- the duties to cooperate, ${ }^{52}$ give prior notification, ${ }^{53}$ and negotiate or consult on activities that may have significant adverse transboundary environmental effects; ${ }^{54}$ 
- the common heritage of humankind, namely, that areas of the global commons (for example, Antarctica, outer space and the moon, the high seas and certain cultural sites) shall not be appropriated by any state, shall be used for peaceful purposes, and shall be managed internationally, and the benefits thereof shall be equitably shared ${ }^{55}$ and

- rights of passage and other rules regarding national jurisdictional zones over the oceans. ${ }^{56}$

Now, even if not rising to the level of custom, these principles may well constitute general principles of law, and hence still formally form part of the corpus of international environmental law; alternately, they certainly have ideational influence.

\subsubsection{General Principles}

This source of international law refers to elements of the domestic legal orders of 'civilized' states. Accordingly, unlike with custom, general principles are not concerned with substantive regularities of behaviour by states in their international interactions. Rather, the focus here is on principles that animate a wide array of domestic legal systems. In a nutshell, general principles of law involve commonly shared procedural elements of domestic legal systems. General principles include res judicata, estoppel, equality of arms, neutrality of decision-makers, methodologies of legal interpretation or reasoning, and equity.

Sustainable development has attracted discussion regarding whether it constitutes a general principle of law. Our Common Future defines 'sustainable development' as 'development that meets the needs of the present without compromising the ability of future generations to meet their own needs' (Our Common Future, attached to GA Res. 43/427 (1987), Ch. 2, para. 1). ${ }^{57}$ The ICJ was called upon to assess whether sustainable development rose to the level of international custom or a general principle of law in the 1997 Gabc íkovo-Nagymaros judgment, which arose from a dispute between Slovakia and Hungary. Hungary's decision to discontinue work on a locks project on the Danube River triggered the dispute. The project had initially been agreed to in an international treaty. Hungary notified Slovakia that it was terminating the treaty. Slovakia persevered with the project, resulting in a significant downstream flow in the Danube that affected Hungary's interests. The dispute was submitted to the ICJ. The ICJ held that 'ecological necessity' was not a circumstance that precluded the wrongfulness of Hungary's treaty breach. The ICJ also held that Slovakia's unilateral activities following the breach constituted an internationally wrongful act in that they interfered with an international watercourse. The ICJ ordered both parties to negotiate in good faith. The ICJ identified sustainable development as a 'concept' and directed the disputants to avail themselves of it in resolving their dispute (para. 140). The ICJ also noted that 'vigilance and prevention are required on account of the often irreversible character of damage to the environment' (para. 140). In a separate opinion, however, Judge Weeramantry elaborated at great length about the status of sustainable development in international environmental law. He held that sustainable development is much more than 'a mere concept', but is a 'principle with normative value' that is 'an integral part of modern international law' crucial to the dispute between Hungary and Slovakia and also 'likely to play a major role in determining important environmental disputes of the future' (Sep. Op. Judge Weeramantry). He extensively discussed the acceptance of sustainable development by actors of international law, and girded this discussion with explicit references to both customary international law and general principles of law. 
Equity serves as a general principle of law. Furthermore, the ICJ also can turn to ex aequo et bono, if the parties are in agreement, as a basis to settle a dispute.

A particularly insightful application of equity to the context of international environmental law is the principle of intergenerational equity developed by Edith Brown Weiss (Weiss, 1989). This principle posits that each generation is to leave its successor generation an environment in no worse condition, leading to the notion that today's generations are under a trusteeship obligation to steward planetary resources for future generations. International environmental law also is animated by the notion of intra-generational equity, which the South posits grounds a moral obligation in the North to share resources and technologies so that the South can pursue its industrialization but do so in a manner that is environmentally sustainable.

\subsubsection{Subsidiary Sources}

\subsubsection{Judicial decisions}

In addition to previously discussed judgments by the ICJ, the ECtHR, and national courts in a variety of jurisdictions, other judicial bodies have issued opinions of relevance to the content of international environmental law. For example, the International Tribunal for the Law of the Sea (ITLOS) has discussed the duty to consult (MOX Plant case) and the precautionary principle (Southern Bluefin Tuna cases). ${ }^{58}$ Although not 'judicial' in a strict sense, the World Trade Organization Dispute Settlement Panels, and the Appellate Body, also have issued important reports, for example in the Shrimp/Turtle, Asbestos, and Hormones disputes. ${ }^{59}$ Federal courts in the United States have assessed the content of international environmental law, in particular customary international environmental law, within the framework of civil claims brought under the Alien Tort Claims Act for violations of the 'laws of nations' (Sarei v. Rio Tinto, 2006; Flores v. Southern Peru Copper Corporation, 2003; Beanal v. Freeport-McMoran, Inc., 1999). ${ }^{60}$ These judgments have tended not to view customary international environmental law as particularly robust, in particular in regard to its reach to intranational pollution. International arbitration has also proved to be influential in the process of international environmental law-making. A well-known international arbitration is the Trail Smelter dispute between Canada and the United States, which involved toxic fumes drifting from a Canadian smokestack across the US border in the Rocky Mountains (Trail Smelter Arbitral Decision, 1939: 182; Trail Smelter Arbitral Decision, 1941: 684; Bratspies and Miller, 2006). The arbitral decision was an early articulation of the obligation not to cause transboundary environmental harm 'when the case is of serious consequence and the injury is established by clear and convincing evidence' (Trail Smelter Arbitral Decision, 1941: 716). The arbitral decision also instantiated the obligation to make reparation.

\subsubsection{Publicists}

Although the ILC is not the main law-making body in the international environmental law area, it has (albeit partially) responded to the need to protect the environment. The ILC has made several contributions to the process of codification and progressive development of international environmental law (Arevalo, 2005). The ILC's draft articles on state responsibility have been of great influence as a subsidiary means for determining international law. ${ }^{61}$ State responsibility involves the consequences to states of their internationally wrongful activities. The law of state responsibility is concerned with what happens after a primary international legal obligation has been breached (Drumbl, 2006: 86). State responsibility 
claims have rarely been invoked in the environmental context. The ILC also has addressed state liability, which involves the obligation by states to compensate for the harm they cause through lawful activities, and more particularly allocation of loss. These topics bear more directly upon the environmental context. Within this broad subject, the ILC has also developed draft articles on the prevention of transboundary harm from hazardous activities. ${ }^{62}$ The ILC's work on prevention underscores the notion that environmental harm is best anticipated instead of remediated through dispute resolution after the fact. The ILC has also developed draft articles on the non-navigational uses of international watercourses. Finally, the ILC has established two working groups specifically related to the protection of the environment. At the meeting in 2017, the ILC decided to establish a Working Group on the topic 'Protection of the environment in relation to armed conflicts'. The second Working Group, on 'Protection of the atmosphere', will deal, as the Special Rapporteur Shinya Murase indicated, with the interrelationship between the rules of international law relating to the protection of the atmosphere and other relevant rules, including the rules of international trade and investment law, the law of the sea, and international human rights law (Murase, 2014: 542-6). The focus will be on analysing 'the obligations of States to prevent atmospheric pollution and mitigate atmospheric degradation, the requirement of due diligence and environmental impact assessment, questions concerning sustainable and equitable utilization of the atmosphere, and the legal limits on certain activities aimed at intentional modification of the atmosphere' (United Nations, 2016, Report of the International Law Commission: 281).

\subsubsection{Soft Law}

Soft law involves instruments that are 'not yet or not only law' (Dupuy, 1991: 420). Although largely consensus-based, and contributive to the elucidation of further consensus, soft law documents are formally non-binding. However, they serve a social constructivist function. Moreover, states, in their subsequent practice, often rely on soft law documents 'to justify their legal rights and duties' (Dupuy, 1991: 422). Soft law can be created intergovernmentally, in conferences or assemblies in which states participate, or non-governmentally.

The United Nations General Assembly is an important locus of soft law-making activity. Member states of the United Nations, through their delegates, have adopted a number of resolutions that pertain to the content of international environmental law. An example is the General Assembly's Resolution on Development and Environment, which 'recognize[d] that no environmental policy should adversely affect the present or future development possibilities of the developing countries' (GA Res. 26/2849, 1971: para. 3). However, with a vote of 85 to 2 (with 34 abstentions), with the US and UK voting against and many other developed countries abstaining, this Resolution bears limited law-like value. After all, the law-like nature of a soft law document hinges upon the clarity and specificity of the language, any conditions attached thereto, any evidence of an expectation of adherence, the numbers of approving/disapproving states, the enthusiasm of the support and the tenor of the opposition, and whether those most affected by the purported law-like instrument actually support it (see Texaco Overseas Petroleum et al. v. Libyan Arab Republic, 1978). In this vein, though of somewhat greater normative currency (in the area of wildlife conservation), the World Charter for Nature was adopted as a General Assembly Resolution in 1982 with one objector (the US) and 18 abstentions (mostly Latin American countries asserting robust sovereignty over natural resources). 
On each of these indicators of law-like value, the Stockholm and Rio Declarations fare very well and thereby constitute the most important general soft law instruments in international environmental law. ${ }^{63}$ Principle 1 of the Stockholm Declaration, although not formally declaring an unequivocal right to a healthy environment, does provide that human beings have a 'fundamental right' to 'adequate conditions of life, in an environment of a quality that permits a life of dignity and well-being'. Principle 1 therefore introduces the implicit human right to a healthy environment. Principle 1 also introduces the idea of intergenerational stewardship by providing that 'Man ... bears a solemn responsibility to protect and improve the environment for present and future generations'. This principle has informed much of international environmental law and subsequently has been revisited in hard law documents at the national and international levels. Moreover, the state obligation not to cause harm to the environment of another state or the global commons, which is affirmed in Principle 21 of the Stockholm Declaration (and discussed above at Section 1.3.2), 'is widely viewed as reflecting customary international law' (Hunter, Salzman and Zaelke, 2007: 465). Soft law instruments, therefore, can serve an important codification and progressive development purpose, similar in effect to the work of the International Law Commission.

The Rio Declaration builds upon many of the principles articulated by the Stockholm Declaration, thereby demonstrating the interconnectedness and sedimentary nature of soft law-making. To Stockholm, Rio added important insights related to the interplay of environment and development in a manner that was protective of the developmental imperative (Rio Declaration, 1992: Principle 3). ${ }^{64}$ The right to development, another concept that has considerable influence in international environmental law, has been reaffirmed by the United Nations General Assembly (GA Res. 55/108, 2001) and the Johannesburg Declaration. The Rio Declaration and Agenda 21 also reference the polluter pays principle, an economic doctrine that encourages market prices to internalize the environmental costs of production (Rio Declaration, 1992: Principle 16; Agenda 21, 1992: para. 30.3).

Non-governmental organizations, commissions created by international organizations and epistemic communities can also create soft law. Dupuy, for example, cites the examples of the 1982 International Law Association's adoption of the Montreal Rules of International Law Applicable to Transfrontier Pollution and the Institute of International Law's promulgation of resolutions on the Utilization of Non-Maritime International Waters, on the Pollution of Rivers and Lakes, and on Transboundary Air Pollution (Dupuy, 1991: 423-4). Other examples include Only One Earth (the background report to the Stockholm Conference (Stockholm Conference, 1972)) and Our Common Future (the Brundtland Report (Brundtland Commission, 1987)).

\subsubsection{Other Concepts, Including Ethics and Ecology}

Important scholarly work on justice (Stone, 1993; Cullet, 1999: 549; Shue, 1999: 531), morality and fairness (Dobson, 1999; Franck, 1995), deep ecology (Lovelock, 1979), environmental ethics (Leopold, 1949; Taylor, 1986), Earth justice (Berry, 1999; Burdon, 2011; Thiong'o, 2011; Mason, 2011; Westra, 2011), economics and externalities (Coase, 1960: 1), cosmopolitanism (Appiah, 2006) and collective action (Hardin, 1968: 1243) indirectly inform the content and interpretation of international environmental law. Natural law also influences international environmental law. ${ }^{65}$ Many scholars and practitioners find the current legal framework for the protection of nature insufficient, as is evident from the writings of some of the previously men- 
tioned authors. Other authors consider, for example, deep ecology as being based on 'different philosophical assumptions than those shared by the majority of people in the world today' (Louka, 2006: 17). That, however, may also be just an assumption. Admittedly, any expansion in terms of the protection of nature (and its rights) in law and public policy will be difficult and considered by many as a controversial, odd or indeed laughable endeavour (by contrast, see Louka, 2006: 16-18). Can, for example, the ecosystem itself be named as the injured party, with its own legal standing rights? Can rivers or trees?

The efforts of many actors in recent years have led to the development of 'Earth Jurisprudence', a term first coined by Thomas Berry, 'the father of environmentalism', spiritual ecologist, Catholic priest and former professor at Fordham University. Berry was of the view that all our institutions, including governments, universities, corporations, religions and especially the legal systems underpinning them rest upon 'a mode of consciousness that has established a radical discontinuity between the human and other modes of being and the bestowal of all rights on the humans' (Berry, 1999: 48). Indeed, the Supreme Court of India recognized this years later by stating:

Laws are man-made, hence there is likelihood of anthropocentric bias towards man, and rights of wild animals often tend to be of secondary importance but in the universe man and animal are equally placed, but human rights approach to environmental protection in case of conflict, is often based on anthropocentricity. (T.N. Godavarman Thirumulpad v. Union of India \& Others, 2012: para. 9)

Earth Jurisprudence is described as 'an inclusive and systems-based theoretical perspective' (Koons, 2011: 45) that seeks to 'redefine the relationship between human beings and the environment by abandoning the anthropocentrism of much contemporary legal theory in favour of an ecocentric perspective' (Alexander, 2011: 293). Earth Jurisprudence reflects the interlinkage between Earth justice and social justice and relates to recently evoked concepts such as global public goods (e.g. climate change or rate of biodiversity loss), global commons (e.g. the high seas, Antarctica or outer space) or fundamental values (the protection of the environment). Earth Jurisprudence draws to a large extent from the cosmologies of indigenous peoples and from the customary law and practices of people in Africa, India, New Zealand and elsewhere; last but not least, it is inspired by the writings of visionaries such as Thomas Berry and Aldo Leopold (Cullinan, 2011: 22).

Various scholars explore and promote Earth Jurisprudence especially through the legal doctrines of standing, the public trust doctrine, intergenerational equity and ecological integrity (Koons, 2011: 45; Westra, 2011: 324). In his article on fraternity as the unspoken third pillar of democracy, Justice Gonthier also explored this third forgotten element of the French Revolution in the context of environmental protection. He suggested that when considering environmental measures, we do not necessarily act in rational self-interest, 'for we as individuals often would not see the fruits of our sacrifice' (Gonthier, 2000: 573). We rather do so in order 'not to harm future inhabitants of this Earth - in essence, we are protecting the next generation' (Gonthier, 2000: 573). Other scholars are a bit more hesitant. Fitzmaurice, for example, describes intergenerational equity as 'a noble attempt to accommodate future generations regarding environmental protection', but she remains doubtful whether from a legal point of view 'such a theory is a workable and practical proposition' (Fitzmaurice, 2008: 229). Certainly, some of these doctrines need to be tested more thoroughly in practice in order to see whether they are indeed viable and useful. Yet, some states, such as Bhutan, incorporate intergenerational equity directly into their constitution. The Bhutan Constitution states that its 
parliament may in fact enact environmental legislation to 'maintain intergenerational equity' (Article 5(4)). The Bhutanese 2007 National Environment Protection Act then codifies that 'the present generation must ensure that the health, diversity and productivity of the environment are maintained or enhanced for the benefit of future generations' (Article 6).

Ecological integrity is a generic concept found not only in the literature, but also in existing law, both domestic and international (e.g. 1971 Ramsar Convention, 1972 US Clean Water Act, 1972 Great Lakes Water Quality Agreement between Canada and the United States, 2004 Berlin Rules on Water Resources or 2015 Paris Agreement). Ecological integrity is vital for the rights to life, to health, to food and to water (Westra, 2011: 325). As such, an effective exercise of these basic rights relies on an ecologically sound assessment of the public policy.

As regards the issue of legal standing, Christopher Stone, a professor at the University of Southern Carolina, published in 1972 his seminal article entitled 'Should Trees Have Standing? Towards Rights for Natural Objects'. Stone argued that if our 'circle of concern' led to the recognition of more extensive legal rights for women, children, Native Americans and African Americans, he was of the view that increasing public concern for protecting nature could equally lead to the recognition of rights of nature, which would allow for "legal suits to be instituted on behalf of trees and other "natural subjects" and damages to be recovered and applied for their benefit' (Cullinan, 2011: 19). Stone proposed to grant legal rights to oceans, rivers, forests and indeed, 'to the natural environment as a whole' (Stone, 1972: 456).

In order to give voice to those unable to speak (including, for example, people with mental disabilities), we regularly resort to guardians and trustees. For example, both federal and state agencies in the United States already fulfil the roles of guardians and trustees of natural entities that have suffered damage, such as public lands, marine mammals and 'natural resources' (Koons, 2011: 49). By comparison, Bhutan places a strong emphasis on environmental protection:

Every Bhutanese is a trustee of the Kingdom's natural resources and environment for the benefit of the present and future generations and it is the fundamental duty of every citizen to contribute to the protection of the natural environment, conservation of the rich biodiversity of Bhutan and prevention of all forms of ecological degradation including noise, visual and physical pollution through the adoption and support of environment friendly practices and policies. (2008 Constitution, Article 5(1))

When advocating the guardianship approach back in 1972, Stone was aware of possible objections being raised; namely, that a guardian could not judge, for example, the needs of the river or forest in its charge. To his mind, there is not much force in such arguments because

natural objects can communicate their wants (needs) to us, and in ways that are not terribly ambiguous. I am sure I can judge with more certainty and meaningfulness whether and when my lawn wants (needs) water, than the Attorney General can judge whether and when the United States wants (needs) to take an appeal from an adverse judgment by a lower court. The lawn tells me that it wants water by a certain dryness of the blades and soil ...; how does 'the United States' communicate to the Attorney General? For similar reasons, the guardian-attorney for a smog-endangered stand of pines could venture with more confidence that his client wants the smog stopped, than the directors of a corporation can assert that 'the corporation' wants dividends declared. We make decisions on behalf of, and in the purported interests of, others every day; these 'others' are often creatures whose wants are far less verifiable, and even far more metaphysical in conception, than the wants of rivers, trees, and land. (Stone, 1972: 471) 
In the same year, the doctrine of legal standing of individuals and groups to bring suit to enforce legal provisions for the protection of the environment was tested in Sierra Club v. Rogers C.B. Morton. Although the Supreme Court of the United States held that the Sierra Club did not have the locus standi to bring the suit since it had not suffered a 'legal wrong', Stone's article inspired the famous dissenting judgment by Justice Douglas:

The critical question of 'standing' would be simplified and also put neatly into focus if we fashioned a federal rule that allowed environmental issues to be litigated before federal agencies or in the name of the inanimate object about to be despoiled, defaced, or be invaded by roads and bulldozers and where the injury is the subject of public outrage. Contemporary public concern for protecting nature's ecological equilibrium should lead to the conferral of standing upon environmental objects to sue for their own preservation. (Sierra Club v. Rogers C.B. Morton, 405 US 727, 741-2 (1972))

In sum, many (legal) approaches to stronger protection of the nature are possible, and these may 'range from the monetary valuation of ecosystem services to the development of schemes for limiting carbon emissions, to cases that would be tried in conventional courts of law for the transgression of boundaries' (Harding and White, 2016). Indeed, in 2018, the ICJ rendered a judgment in consolidated cases re delimitation of land and maritime boundaries between Costa Rica and Nicaragua. In respect of 'the monetary valuation of ecosystem services', the ICJ said as follows:

The Court is therefore of the view that damage to the environment, and the consequent impairment or loss of the ability of the environment to provide goods and services, is compensable under international law. Such compensation may include indemnification for the impairment or loss of environmental goods and services in the period prior to recovery and payment for the restoration of the damaged environment. Payment for restoration accounts for the fact that natural recovery may not always suffice to return an environment to the state in which it was before the damage occurred. In such instances, active restoration measures may be required in order to return the environment to its prior condition, insofar as that is possible. (Certain Activities Carried Out by Nicaragua in the Border Area, 2018: paras. 42-3)

There is surely a need to clarify and systematize Earth-oriented concepts. But there is also enough evidence of Earth Jurisprudence in existing law, which proves that Earth Jurisprudence is not just a fanciful philosophy. We may find some evidence even in the constitutions of some states. Constitutions usually determine the position of international law and corresponding principles within the domestic legal system of the country, and new constitutions adopted after armed conflicts, a change of (undemocratic) regime or other forms of transitions (e.g. Bhutan's transition to a constitutional monarchy) often place a strong emphasis on international law. Conversely, international law often reconceptualizes the constitution and affects the domestic legal system as a whole (Uhlírová, 2012: 199). Practical illustration of Earth Jurisprudence and Earth-centred governance that may be setting an international example can be found in the constitutions or laws and practice of the following countries:

- New Zealand's National Parks Act 1980 is founded on principle that national parks will be protected in perpetuity for their 'intrinsic worth' (Article 4(1)). New Zealand also adopted the Treaty of Waitangi principles, which can be referred to in Acts of Parliament. The Treaty of Waitangi contains protection of Maori interests including interests in or associations with land. In 2017, New Zealand's government has recognized the Whanganui River as a legal person when the Parliament passed a historic bill. 'This bill is an innovative 
and world-leading solution to a very complex and, at times, a very, very controversial issue', said Nuk Korako, chair of the Māori Affairs Committee. The bill declares that the Whanganui River 'is an indivisible and living whole [and comprises] the Whanganui River from the mountains to the sea, incorporating all its physical and metaphysical elements' and is a legal person with 'all the rights, powers, duties, and liabilities of a legal person' (Whanganui River Claims Settlement Bill, 2017). An indigenous group will now represent the interests of the Whanganui River. The same status was also granted to Te Urewera (once a national park) in 2014.

- India's National Wildlife Action Plan 2002-2012 and centrally sponsored scheme (Integrated Development of Wildlife Habitats) are based on ecocentrism, and Indian courts are quite progressive in terms of environmental protection. The K.M. Chinnappa $v$. Union of India (2002) case dealt with the extension of a mining lease granted to the mining company. In this case, the Supreme Court of India endorsed the 1983 World Charter for Nature and stated that by 'destroying nature, environment, man is committing matricide, having in a way killed Mother Earth', and emphasized a duty of care to protect the environment. In T.N. Godavarman Thirumulpad v. Union of India \& Others (2012), the Supreme Court recognized that under the Constitution, 'human interest[s] do not take automatic precedence [over the environment] and humans have obligations to nonhumans independently of human interest', and added that 'Environmental justice could be achieved only if we drift away from the principle of anthropocentric to ecocentric'. Only a few days after the Whanganui River was probably the first river in the world to be granted legal personhood, the rivers Ganga and Yamuna were too recognized as possessing legal personhood by the Uttarakhand High Court:

Accordingly, while exercising the parens patrie jurisdiction, the Rivers Ganga and Yamuna, all their tributaries ... are declared as juristic/legal persons/living entities having the status of a legal person with all corresponding rights, duties and liabilities of a living person in order to preserve and conserve Rivers Ganga and Yamuna. The Director NAMAMI Gange, the Chief Secretary of the State of Uttarakhand and the Advocate General of the State of Uttarakhand are hereby declared persons in loco parentis as the human face to protect, conserve and preserve Rivers Ganga and Yamuna and their tributaries. These Officers are bound to uphold the status of Rivers Ganges and Yamuna and also to promote the health and wellbeing of these rivers. (Mohd. Salim v. State of Uttarakhand \& Others, 2017: para. 19)

- In the United States, many towns and communities adopted local laws recognizing the rights of nature. In 2006, the town of Barnstead in New Hampshire adopted a Barnstead ordinance, which 'recognises that ecosystems have legally enforceable rights' and 'strips corporations of constitutional protections' (Margil, 2011: 253). Barnstead was the first community in the US to prohibit corporations privatizing their water (Margil, 2011: 253).

- In context of the loss of biodiversity worldwide, Bhutan's conservation achievements are remarkable. Under the 2008 Constitution, a minimum of 60 per cent of Bhutan 'shall be maintained under forest cover for all time' (Article 5(3)). In addition to that, more than 50 per cent of the land is designated as protected in national parks, nature reserves and biological corridors and 'its record on carbon sequestration is greater than its national emissions by a factor of two' (Jeffree, 2013). These objectives are coupled with, or perhaps rather result from, 'A very strong eco-ethical sentiment found in the Buddhist belief that all actions should bring the most help and least harm to other sentient beings' (Jeffree, 2013). 
Overall, Bhutan's environmental successes demonstrate that it is possible to combine sustainable development while preserving high biodiversity. Admittedly, this may prove a very challenging road to travel in the near future. So far, environmental sustainability is the key concept for Bhutan:

Bhutan has a long tradition of living in harmony with nature, which is reaffirmed by the resolution of the Parliament to maintain a minimum of sixty percent of country's land under forest cover in perpetuity ... environmental sustainability is an essential element of the Development Philosophy - 'Gross National Happiness,' conceived by His Majesty the King. (The 2007 National Environment Protection Act, Preamble)

- Use of customary law in Kenya (and, for that matter, in Africa generally) faces many challenges, including the issue of how to restore it so 'it sits next to common law' (Thiong'o, 2011: 176). Nevertheless, Kenya has an inspiring customary justice system, which was described as non-retributive, non-punitive, restoring and healing (Thiong'o, 2011: 175). Kenya also adopted the Environmental Coordination and Management Act 1999, which includes principles of Earth Jurisprudence, and the Forest Act 2005, which recognizes indigenous knowledge in the local governance of the forests.

- South Africa has a good example of community ecological governance contained in the South African National Environmental Management Act (see cases in Section 1.2.7: State v. Golfview Mining (Pty) Ltd and State v. Blue Platinum Ventures PTY LTD \& Maponya). At the same time, however, the Act remains predominantly anthropocentric in its focus.

- Ethiopia has limited, but some examples of, legal and other instruments that reflect ecocentric views: the Federal Democratic Republic of Ethiopia Constitution (Article 92(2) and (4)), the Environmental Policy of Ethiopia (section 2(3)(q)) and the customary environmental protection practices and cosmological aspects of traditional cultures of Amhara and Southern Region and Oromo people.

- Bolivia passed the Law of Mother Earth, backed up by a Ministry of Mother Earth, an inter-Ministry Advisory Council, and an Ombudsman.

- Mexico's Environmental Law for the protection of the Earth, adopted in 2013, recognizes Earth's rights to exist and flourish.

- The Supreme Court of Belize in Ms Westerhaven Schiffahrts GMBH \& CO KG Redier Shipping $B V$ v. The Attorney General of Belize recognized coral reefs not merely as 'property' but as 'actual living ecosystems' (para. 11). The case involved the container ship Westerhaven causing damage to the barrier reef by the grounding of the ship. The government of Belize (GOB) successfully sued the ship's owners for damages with the Supreme Court of Belize affirming the award of $\$ 11,510,000$ to GOB (para. 132). With regard to one of the major issues in the case, GOB's leading expert witness at the trial, McField, asserted that

the living reef ecosystem and the services it provides are not the 'property' of anyone. The reef cannot be bought or sold ... In fact, several years ago two private investors attempted to lease a section of the reef from [GOB] as a tourism management concession. Their efforts were unsuccessful due to public outrage at the suggestion that the nation's coral reef could be leased as property to any private entity. The Belize reef is certainly part of the nation's natural capital and public assets, capable of providing revenue generation and valuable ecosystem services for millennia to come, if its functional integrity is maintained. (Ms Westerhaven Schiffahrts GMBH \& CO KG Redier Shipping BVv. The Attorney General of Belize, 2010: para. 24) 
- Ecuador goes the furthest: the rights of Nature were adopted in the 2009 Constitution (Articles 71-4). By so doing, Ecuador moved the discussion from 'whether or not it was possible to recognize rights of Nature to whether or not doing so would be effective' (Cullinan, 2011:21). Cullinan's comment on effectivity of such a framework is well made, as evidenced, for example, by the situation of the Shuar People in Ecuador. In the context of the right to the collective property of indigenous peoples over their territories and natural resources, leaders of the Shuar People reported to the Inter-American Commission on Human Rights that the extractive policy contradicts the constitutional principles and the worldview of the affected people:

We want to say that the Shuar are not opposed to development, as it is said by the Government, army and companies. We have an example of an oil company that has existed in Amazonia for more than 40 years where there are multiple nationalities. But the development that they refer to is incompatible with the way of thinking of the people ... we request that the State, in accordance with the Constitution, guarantees the existence of indigenous peoples, but, instead, it kills. (IACmHR, 2015)

Needless to say, the above-mentioned cases, statutes, regulations and constitutional instruments may all amount to state practice, which clearly includes 'not just the practice of the government of a State but also of its courts and parliament' (Greenwood, 2008). Moreover, many of those states are mostly and directly affected by devastating or otherwise harmful activities of various actors, including corporations. For example, the Ecuadorian rainforest was exposed to more than 18 billion gallons of toxic wastewater disposed of by Texaco (Margil, 2011: 254). This clearly increases the relevance of affected states' contributions in the context of (international) environmental law.

In addition to the variety of domestic regulatory sources, the emergence of informal or international soft law is highly relevant. Many of the following documents recognize the Earth to have a value 'in its own right regardless of any particular value it may have to the human species' (Mason, 2011: 41; cf. Louka, 2006: 17). These sources include the: 1972 Stockholm Declaration; 1983 World Charter for Nature; 1991 Caring for the Earth (World Conservation Union); 1992 Declaration of the Parliament of World Religions; 1996 Earth Charter; 1997 Declaration on the Responsibilities of the Present Generations towards Future Generations; 2000 Millennium Development Goals; 2000 A Manifesto for Earth; 2002 A Manifesto for Life; and 2010 Universal Declaration of Rights of Mother Earth (The International Tribunal for the Rights of Nature).

The Earth Charter, signed by over 2 million people worldwide, involved 'the most inclusive and participatory process ever associated with the creation of an international declaration' (The Earth Charter Initiative). It was formally recognized by 4800 organizations (e.g. UNESCO) and many governments. Most recently, terms such as 'intergenerational equity', 'Mother Earth' and 'climate justice' occurred in the Preamble of the Paris Agreement, which reads: 'Noting the importance of ensuring the integrity of all ecosystems, including oceans, and the protection of biodiversity, recognized by some cultures as Mother Earth, and noting the importance for some of the concept of "climate justice" when taking action to address climate change' (emphasis added). Hopefully there will be gradually more 'someones' given the fact that the likelihood of global warming of at least 2 degrees Celsius will result in the compromise of all major ecosystems of Mother Earth, affecting us all. 
So far, an anthropocentric approach remains dominant, but it 'arguably faces its most significant challenge in history' (Kauffman, 2017: 204). Even if many ideas seem too idealistic or improbable, as Sands mentioned with regard to Earth Jurisprudence, 'experience teaches us that what may [be] seen as over-arching at one time soon becomes conventional wisdom' (Mason, 2011: 44). Stone noted in 1972: 'How far we are from such a state of affairs, where the law treats "environmental objects" as holders of legal rights, I cannot say' (Stone, 1972: 501). Not that far, perhaps. Many have already spoken, and not only for trees:

So we have come a long way since that time when we were ridiculed for actually putting our point of view forward, to the extent now that we are legitimising Māori concepts in law. I can imagine how outside of these walls the country will be going off: 'Oh, my gosh! These Māoris - what are they on about now?' Well, if in our Pākehā culture and in our Christian culture we believe someone can walk on water, then we can believe that Te Awa o Whanganui is a person. So it is a beautiful thing. (Kelvin Davis, Labour-Te Tai Tokerau, Whanganui River Claims Settlement Bill - First Reading, 2016)

\subsection{CONCLUSION}

This chapter has surveyed the array of actors that dynamically make international environmental law through a variety of sources. However, despite the growing legalization of international environmental policy, indicators suggest that the quality of the global environment has deteriorated (Programme for the Further Implementation of Agenda 21, 1997: paras. 9-10). Climate change presents a stark example. ${ }^{66}$ Legalization in treaties and custom, and acceptance of principles such as sustainable development, do not ineluctably lead to measurable improvements in the global environment. Looking ahead, international environmental law likely faces its greatest challenges on issues of effectiveness and compliance.

\section{NOTES}

1 Moreover, the ICJ may consider ex aequo et bono as a source of law if the parties agree thereto.

2 'Even individuals and corporations or other juridical entities can be persons under or subjects of international law when they are accorded rights, duties and other aspects of legal personality under customary international law or an international agreement' (see also: Kirgis, 1993).

3 List of Members of the United Nations accessible at http://www.un.org/members/list.shtml (last accessed 4 May 2020).

4 Accessible at https://www.cia.gov/library/publications/resources/the-world-factbook/index.html (last accessed 4 May 2020).

5 Joining the US, Canada, and Australia in multilateral biosafety negotiations were industrializing nations such as Argentina, Chile, and Uruguay - to form what was referred to as the Miami Group. The Miami Group consists of large exporters of genetically modified organisms.

6 This is a somewhat unsettled area of international law.

7 This Resolution was passed six months in advance of the Stockholm Conference, was strongly supported by developing countries, and was aimed at influencing the outcome of the conference.

8 For more detailed treatment of the structure and activities of international organizations in the field of international environmental law, see Ulfstein, Chapter 4 in this volume.

9 Established by GA Res. 27/2997, 15 December 1972.

10 Charged with poverty alleviation and promotion of economic development, UNDP has expanded into the environmental area by virtue of the principle of sustainable development. It has significantly more funds at its disposal than UNEP.

11 Established by GA Res. 47/191, 29 January 1993, following the Rio Conference. 
12 Ulfstein reports that 'Since 1991 GEF has financed projects in more than 160 developing countries and countries with economies in transition', see Ulfstein, Chapter 4 in this volume.

13 For a contrary perspective, see Najam (2003: 367). For a general overview see Biermann and Bauer (2005).

14 On the derivative right to information in environmental matters, see Guerra and Others v. Italy, 1998: 357.

15 Noting that 'The harms associated with climate change are serious and well recognized' and also providing details of the specifics of such harms.

16 Accessible at http://www.ohchr.org/english/issues/environment/environ/bp4.htm\#_ftn88 (last accessed 4 May 2020).

17 For more detailed treatment of the structure and activities of treaty secretariats and conferences of the parties in the field of international environmental law, see Ulfstein, Chapter 4 in this volume; Churchill and Ulfstein (2000: 623).

18 See also Ulfstein, Chapter 4 in this volume, discussing the Consultative Meeting of the Parties to the Convention on the Prevention of Marine Pollution by Dumping of Wastes and Other Matter.

19 See for example United Nations Convention to Combat Desertification, accessible at http://www .unccd.int/ (last accessed 4 May 2020); Convention on Biological Diversity, accessible at http:// www.cbd.int/ default.shtml (last accessed 4 May 2020); FCCC, accessible at http://unfccc.int/2860 .php (last accessed 4 May 2020); Vienna Convention for the Protection of the Ozone Layer, accessible at http://www.unep.ch/ozone/About_the_Secretariat/index.shtml (last accessed 4 May 2020); Convention on International Trade in Endangered Species of Wild Fauna and Flora, accessible at http://www.cites.org/ (last accessed 4 May 2020).

20 See for example the Subsidiary Body on Scientific, Technical and Technological Advice created by Art. 25 of the Convention on Biological Diversity.

21 Accessible at http://www.icbl.org/treaty (last accessed 4 May 2020). The ICBL, which operates an office in Geneva, currently has six staff members.

22 Ibid.

23 Discussing the ways that financial regulators exchange information and expertise.

24 ' $\mathrm{N}]$ etworks of national government officials [are] exchanging information, coordinating national policies, and working together to address common problems.'

25 'An epistemic community is a network of professionals with recognized expertise and competence in a particular domain and an authoritative claim to policy-relevant knowledge within that domain or issue-area.'

26 Reference is made to the 1995 Report of the IPCC.

27 Accessible at http://www.iso.org/iso/en/ISOOnline.frontpage (last accessed 4 May 2020).

28 'The decision of the Court has no binding force except between the parties and in respect of that particular case.'

29 Art. 38(2) states: 'This provision shall not prejudice the power of the Court to decide a case ex aequo et bono, if the parties agree thereto.'

30 The Vienna Convention on the Law of Treaties also reflects customary international law.

31 Vienna Convention on the Law of Treaties between States and International Organizations or between International Organizations (1986).

32 For a discussion of this phenomenon in the context of the Montreal Protocol, see Benedick (1998).

33 That is, the Convention between the United States and other Powers Providing for the Preservation and Protection of Fur Seals, 7 July 1911 (between the US, Russia, Great Britain and Japan).

34 See for example the Convention on Long-Range Transboundary Air Pollution (1979) (parties are European countries, plus Canada and the United States); Espoo Convention on Environmental Impact Assessment in a Transboundary Context (1991) (parties are European countries plus Canada and the United States).

35 See https://www.cbd.int/information/parties.shtml (last accessed 4 May 2020).

36 See http://www.cites.org/eng/disc/parties/chronolo.shtml (last accessed 4 May 2020).

37 See http://www.basel.int/ratif/convention.htm (last accessed 4 May 2020).

38 See http://www.unep.ch/ozone/Ratification_status/index.shtml (last accessed 4 May 2020). 
39 See http://unfccc.int/files/essential_background/convention/status_of_ratification/application/pdf/ unfccc rat_130407.pdf (last accessed 4 May 2020). For the Kyoto Protocol, see http://unfccc.int/ kyoto_protocol/ items/2830.php (last accessed 4 May 2020).

40 Accessible at http://www.unccd.int/ (last accessed 4 May 2020).

41 See http://www.ramsar.org/key_cp_e.htm (last accessed 4 May 2020).

42 See http://untreaty.un.org/ENGLISH/bible/englishinternetbible/partI/chapterXXI/treaty6.asp (last accessed 4 May 2020).

43 See http://www.imo.org/Conventions/mainframe.asp?topic_id=247 (last accessed 4 May 2020).

44 States have common responsibilities to protect the environment, but in light of social, economic, and ecological situations, these responsibilities are to be shouldered differentially among states (see for example FCCC, 1992: Preamble, para. 6, Arts 3(1), 4(1); Kyoto Protocol, 1997: Art. 10; Rio Declaration, 1992: Principle 7): 'In view of the different contributions to global environmental degradation, States have common but differentiated responsibilities.'

45 The CBD and FCCC preambles assert that 'the conservation of biological diversity is a common concern of humankind' and that 'change in the Earth's climate and its adverse effects are a common concern of humankind' respectively. The principle of 'common concern of humankind' must not be confused with the 'common heritage of humanity', discussed below. Whereas common heritage applies to areas of the global commons that lie beyond the reach of national jurisdiction, common concern issues (for example, biodiversity conservation and global warming emissions/sequestration through forests) involve matters that lie within the national jurisdiction of states but impact the global environment. Common heritage was explicitly rejected as extending to the biodiversity and climate change regimes.

46 FCCC Art. 4(7) reads as follows:

The extent to which developing country Parties will effectively implement their commitments under the Convention will depend on the effective implementation by developed country Parties of their commitments under the Convention related to financial resources and transfer of technology and will take fully into account that economic and social development and poverty eradication are the first and overriding priorities of the developing country parties.

See also Convention on Biological Diversity, 1992: Art. 20(4); Montreal Protocol, 1987 (as amended by the London Amendments): Art. 5(5); Drumbl (2002: 917).

47 A party that seeks to dispose of hazardous wastes in another state must inform the importing state of the nature of the wastes and receive that state's written consent; see also Rotterdam Convention on the Prior Informed Consent Procedure for Certain Hazardous Chemicals and Pesticides in International Trade (1998).

48 See for example Convention to Combat Desertification, 1994: Art. 3; Aarhus Convention, 1998; Rio Declaration, 1992: Principle 10.

49 Granting states the sovereign right to exploit their own resources pursuant to their own environmental policies, but also the responsibility to ensure that activities within their own jurisdiction or control do not cause damage to the environment of other states or of common areas beyond national jurisdiction. The following cases are also relevant: Corfu Channel, 1949: 22; Legality of the Threat or Use of Nuclear Weapons, 1996: para. 29.

50 See for example Rio Declaration, Principle 15; Bamako Convention on the Ban of the Import into Africa and the Control of Transboundary Movement and Management of Hazardous Wastes within Africa (1991): Art. 4(3)(f); Stockholm Convention on Persistent Organic Pollutants (2001): Arts 1, 8. The European Union has declared that the precautionary principle is part of customary international law.

51 See for example Rio Declaration, 1992: Principles 4, 17, 25; UNCLOS, 1982: Art. 206; Espoo Convention on Environmental Impact Assessment in a Transboundary Context, 1991: Arts 2, 3. It is noteworthy that "well over 150 countries hav[e] a domestic environmental impact assessment law. Many judicial decisions in many countries have also enforced the obligation to conduct environmental impact assessment under these laws' (Hunter, Salzman and Zaelke, 2007: 533).

52 See for example UN Charter, 1945: Art. 1(3); Rio Declaration, 1992: Principle 27; UNCLOS, 1982: Art. 197; Montreal Protocol, 1987: Art. 9; CBD, 1992: Art. 5.

53 See for example Rio Declaration, 1992: Principle 19; Corfu Channel, 1949: 22.

54 See for example Rio Declaration, 1992: Principle 19; also Lac Lanoux Arbitration, 1957: 101. 
55 See for example UNESCO Convention Concerning the Protection of the World Cultural and Natural Heritage (1972); Treaty on Principles Governing the Activities of States in the Exploration and Use of Outer Space, Including the Moon and Other Celestial Bodies (1967); Agreement Governing the Activities of States on the Moon and Other Celestial Bodies (1979); UNCLOS. The determination of what exactly constitutes a common heritage of humanity remains unsettled; so does the customary status of the principle and whether each of the four enumerated characteristics constitutes custom. See Joyner (1985: 66): 'the most to be posited about the legal status of' the common heritage of humanity is that it is 'an emergent principle of international law.'

56 See generally UNCLOS, which codifies certain of these customs.

57 Sustainable development also is referenced in international treaties. See FCCC, 1992: Arts 3(4), $3(5)$.

58 More information on ITLOS, including its docket and cases, is accessible at http://www.itlos.org (last accessed 4 May 2020).

59 More information on the WTO, including dispute settlement, is accessible at http://www.wto.org (last accessed 4 May 2020).

60 Opinion subsequently withdrawn by Sarei v. Rio Tinto (9th Cir. Cal., 12 April 2007).

61 The 2001 Draft Articles on Responsibility of States for Internationally Wrongful Acts in Crawford (2002). The ILC is responsible for the codification and progressive development of international law.

62 Draft Articles on Prevention of Transboundary Harm from Hazardous Activities, together with Commentaries, ILC Report on the Work of its Fifty-Third Session, 56 UN GAOR Supp. (No. 10) VE 1, UN Doc. A/56/10 (2001).

63 By way of example, the United States attached interpretive statements to its signature to a number of principles of the Rio Declaration, thereby loosely transferring approaches from the law of treaties to its interface with this soft law document. Such a course of conduct attests to the reality that the Rio Declaration reflects a serious level of obligation.

64 'The right to development must be fulfilled so as to equitably meet developmental and environmental needs of present and future generations.'

65 For a discussion of natural law and a contrast with positivism, see Hunter, Salzman and Zaelke (2007: 328-30).

66 Global greenhouse gas emissions have palpably increased since 1990.

\section{REFERENCES}

Alexander, S. (2011), 'The Earth Jurisprudence and the Ecological Case for Degrowth', in P. Burdon (ed.), Exploring Wild Law: The Philosophy of Earth Jurisprudence, Kent Town, South Australia: Wakefield Press, 293-303.

Alston, P. (2005), "The "Not-a-Cat" Syndrome: Can the International Human Rights Regime Accommodate Non-State Actors?', in P. Alston (ed.), Non-State Actors and Human Rights, Oxford: Oxford University Press, 3-36.

Anton, D. et al. (2007), International Environmental Law and Policy: Cases, Materials, Problems, Newark, NJ: LexisNexis.

Appiah, K. (2006), Cosmopolitanism: Ethics in a World of Strangers, London: Allen Lane.

Arevalo, L. B. (2005), 'The Work of the International Law Commission in the Field of International Environmental Law', Boston College Environmental Affairs Law Review, 32, 493-507.

Baker McKenzie (ed.) (2017), 'Environmental Priorities and Management Challenges in a Changing World', International Environmental Law Conference, Chicago, 22-23 June, accessible at https://www .bakermckenzie.com/en/insight/publications/2017/07/-/media/a04bc4a6982a401d992ca32fd01722e5.ashx.

Bales, K. (2016), Blood and Earth: Modern Slavery, Ecocide, and the Secret to Saving the World, New York: Spiegel and Grau/Random House.

Benedick, R. (1998), Ozone Diplomacy, Cambridge, MA: Harvard University Press.

Berry, T. (1999), The Great Work: Our Way into the Future, New York: Bell Tower. 
Biello, D. (2014), 'Everything You Need to Know about the U.S.-China Climate Change Agreement: A Turning Point Has Been Reached in the World's Bid to Curb Global Warming', Scientific American, accessible at https://www.scientificamerican.com/article/everything-you-need-to-know-about-the-u-s -china-climate-change-agreement/.

Biermann, F. and Bauer, S. (eds) (2005), A World Environmental Organization: Solution or Threat for Effective International Governance?, Aldershot: Ashgate.

Bodansky, D. (1999), 'The Legitimacy of International Governance: A Coming Challenge for International Environmental Law?', AJIL, 93(3), 596-627.

Boyle, A. (2000), 'Some Reflections on the Relationship of Treaties and Soft Law', in V. Gowlland-Debbas (ed.), Multilateral Treaty-Making: The Current Status of Challenges to and Reforms Needed in the International Legislative Process, Berlin and Heidelberg: Springer, 34-5.

Bratspies, R. and Miller, R. (eds) (2006), Transboundary Harm in International Law: Lessons from the Trail Smelter Arbitration, Cambridge: Cambridge University Press.

Brown, B. (1994), 'Developing Countries in the International Trade Order', Northern Illinois University Law Review, 14, 347-406.

Brundtland Commission (1987), Our Common Future, Oxford: Oxford University Press.

Burdon, P. (2011), 'The Great Jurisprudence', in P. Burdon (ed.), Exploring Wild Law: The Philosophy of Earth Jurisprudence, Kent Town, South Australia: Wakefield Press, 59-75.

Camenzuli, L. K. (2007), The Development of International Environmental Law at the Multilateral Environmental Agreements' Conference of the Parties and its Validity, accessible at http://cmsdata .iucn.org/downloads/cel10_camenzuli.pdf.

Charnovitz, S. (2002), ‘A World Environment Organization', Columbia Journal of Environmental Law, 27, 323-62.

Churchill, R. R. and Ulfstein, G. (2000), 'Autonomous Institutional Arrangements in Multilateral Environmental Agreements: A Little-Noticed Phenomenon in International Law', AJIL, 94, 623-59.

Clark, D. (2011), 'Which Nations Are Most Responsible for Climate Change?', The Guardian, 21 April 2011, accessible at https://www.theguardian.com/environment/2011/apr/21/countries-responsible -climate-change.

Coase, R. (1960), 'The Problem of Social Cost', Journal of Law and Economics, 3, 1-44.

Crawford, J. (2002), The International Law Commission's Articles on State Responsibility: Introduction, Text and Commentaries, Cambridge: Cambridge University Press.

Cullet, P. (1999), 'Differential Treatment in International Law: Towards a New Paradigm of Inter-State Relations', EJIL, 10, 549-82.

Cullinan, C. (2011), 'A History of Wild Law', in P. Burdon (ed.), Exploring Wild Law: The Philosophy of Earth Jurisprudence, Kent Town, South Australia: Wakefield Press, 12-23.

Damrosch, L. et al. (2001), International Law: Cases and Materials, St. Paul, MN: West.

Davis, K. (2016), 'Whanganui River Claims Settlement Bill - First Reading', New Zealand Parliament, accessible at https://www.parliament.nz/en/pb/hansard-debates/rhr/document/51HansD_20160528 00000012/te-awa-tupua-whanganui-river-claims-settlement-bill.

De Feyter, K. (ed.) (2017), Globalization and Common Responsibilities of States, London: Routledge.

Dobson, A. (1999), Fairness and Futurity, Oxford: Oxford University Press.

Docherty, B. and Giannini, T. (2012), 'YJIL Symposium: Human Rights and Climate Change Adaptation at the International Level', Yale Journal of Law, 37, accessible at http://opiniojuris.org/2012/06/26/ human-rights-and-climate-change-adaptation-at-the-international-level/.

Drumbl, M. (2002), 'Poverty, Wealth, and Obligation in International Environmental Law', Tulane Law Review, 76, 843-90.

Drumbl, M. (2006), 'Trail Smelter and the International Law Commission's Work on State Responsibility for Internationally Wrongful Acts and State Liability', in R. Bratspies and R. Miller (eds), Transboundary Harm in International Law: Lessons from the Trail Smelter Arbitration, Cambridge: Cambridge University Press, 85-98.

Dupuy, P.-M. (1991), 'Soft Law and the International Law of the Environment', Michigan Journal of International Law, 12, 420-35.

Duyck, S. (2015), 'The Paris Climate Agreement and the Protection of Human Rights in a Changing Climate', Yearbook of International Environmental Law, 26, 3-45.

Emmerson, C. (2010) The Future History of the Arctic, New York: Public Affairs. 
Fitzmaurice, M. (2008), 'Intergenerational Equity Revisited', in I. Buffard et al. (eds), International Law between Universalism and Fragmentation, Festschrift in Honour of Gerhard Hafner, Leiden: Brill/ Nijhoff, 195-229.

Franck, T. (1995), Fairness in International Law and Institutions, Oxford: Clarendon Press.

Goisis, F. (2017), 'Human Right to a Healthy Environment in Europe', in Baker McKenzie (ed.) (2017), 'Environmental Priorities and Management Challenges in a Changing World', International Environmental Law Conference, Chicago, 22-23 June, accessible at https://www.bakermckenzie .com/en/insight/publications/2017/07/-/media/a04bc4a6982a401d992ca32fd01722e5.ashx, 14-24.

Gonthier, Ch. D. (2000), 'Liberty, Equality, Fraternity: The Forgotten Leg of the Trilogy, or Fraternity: The Unspoken Third Pillar of Democracy', McGill Law Journal, 45, 567-89.

Haas, P. (1992), 'Epistemic Communities and International Policy Coordination', International Organization, 46, 1-35.

Hardin, G. (1968), 'The Tragedy of the Commons', Science, 162, 1243-8.

Heller, K. and Lawrence, J. (2007), 'The Limits of Article 8(2)(b)(iv) of the Rome Statute, the First Ecocentric Environmental War Crime', Georgetown International Environmental Law Review, 20, $61-95$.

Hermann, V. (2016), 'Arctic Solutions at the COP of Action', High North News, accessible at http:// www.highnorthnews.com/arctic-solutions-at-the-cop-of-action/.

Hunter, D., Salzman, J. and Zaelke, D. (2007), International Environmental Law and Policy, New York: Foundation Press.

Jacquet, J. and Jamieson, D. (2016), 'Soft but Significant Power in the Paris Agreement', Nature Climate Change, 6, 643-6.

Jeffree, R. (2013), 'Bhutan's Environmental Success Is a Pleasing Paradox', The Conversation, accessible at http://theconversation.com/bhutans-environmental-success-is-a-pleasing-paradox-21338.

Joyner, C. (1985), 'Remarks', American Society of International Law, 79, 62-7.

Kamminga, M. T. (1999), 'Holding Multinational Corporations Accountable for Human Rights Abuses: A Challenge for the EC', in P. Alston (ed.), The EU and Human Rights, Oxford: Oxford University Press, 553-69.

Kauffman, C. M. (2017), Grassroots Global Governance: Local Watershed Management Experiments and the Evolution of Sustainable Development, New York: Oxford University Press.

Kirgis, R. (1993), International Organizations in their Legal Setting, St. Paul, MN: West.

Kohli, A. (2015), 'Making Sense of Transparency and Review in the Paris Agreement', Yearbook of International Environmental Law, 26, 46-67.

Koons, J. E. (2011), 'Key Principles to Transform Law for the Health of the Planet', in P. Burdon (ed.), Exploring Wild Law: The Philosophy of Earth Jurisprudence, Kent Town, South Australia: Wakefield Press, 45-58.

Lawrence, P. and Wong, D. (2017), 'Soft Law in the Paris Climate Agreement: Strength or Weakness?', Review of European, Comparative and International Environmental Law, 26, $276-86$.

Leijten, I. (2019), 'Human Rights v. Insufficient Climate Action: The Urgenda Case', Netherlands Quarterly of Human Rights 37(2), 112-8.

Leopold, A. (1949), A Sand County Almanac, Oxford: Oxford University Press.

Loughlin, N. (2016), 'Land Grabs and the International Criminal Court: Will Cambodia's Kleptocrats Finally Face Justice?', Cultural Survival, accessible at https://www.culturalsurvival.org/news/land -grabs-and-international-criminal-court-will-cambodias-kleptocrats-finally-face-justice.

Louka, E. (2006), International Environmental Law, Fairness, Effectiveness, and World Order, New York: Cambridge University Press.

Lovelock, J. (1979), Gaia: A New Look at Life on Earth, Oxford: Oxford University Press.

Margil, M. (2011), 'Stories from the Environmental Frontier, in P. Burdon (ed.), Exploring Wild Law: The Philosophy of Earth Jurisprudence, Kent Town, South Australia: Wakefield Press, 249-58.

Mason, I. (2011), 'One in All: Principles and Characteristics of Earth Jurisprudence', in P. Burdon (ed.), Exploring Wild Law: The Philosophy of Earth Jurisprudence, Kent Town, South Australia: Wakefield Press, 35-44.

Maton, J. (2016), 'ICC Prosecutor Will Also Prioritise Environmental Destruction Cases', iLawyer, accessible at http://ilawyerblog.com/icc-prosecutor-will-also-prioritise-environmental-destruction -cases/. 
Maza, C. (2016), 'ICC Move Fuels Debate on Cambodian Case', The Phnom Penh Post, accessible at http://www.phnompenhpost.com/national/icc-move-fuels-debate-cambodian-case.

Merkouris, P. (2017), 'The UNFCCC and the Kyoto Protocol: The Challenges of Trying to Clean One's Own Nest', in M. Fitzmaurice, A. Tanzi and A. Papantoniou (eds), Multilateral Environmental Treaties, Cheltenham, UK and Northampton, MA, USA: Edward Elgar Publishing, 375-99.

Murase, S. (2014) 'International Law Commission (ILC)', Yearbook of International Environmental Law, 25, 542-6.

Murphy, S. D. (2004-2005), 'Taking Multinational Corporate Codes of Conduct to the Next Level', Columbia Journal of Transnational Law, 43, 389-97.

Najam, A. (2003), 'The Case against a New International Environmental Organization', Global Governance, 9, 367-84.

Palmer, G. (1992), 'New Ways to Make International Environmental Law', AJIL, 86, 259-83.

Razzaque, J. (2002), 'Human Rights and the Environment: The Experience in South Asia and Africa', Office of the United Nations High Commissioner for Human Rights, accessible at http://www.ohchr .org/english/issues/environment/environ/bp4.htm\# ftn88.

Savaresi, A., Cismas, I. and Hartmann, J. (2017), 'The Philippines Human Rights Commission and the “Carbon Majors" Petition', EJIL Talk!, accessible at https://www.ejiltalk.org/the-philippines-human -rights-commission-and-the-carbon-majors-petition/.

Schönfeldt, K. (ed.) (2017), The Arctic in International Law and Policy, Oxford: Hart Publishing.

Shue, H. (1999), 'Global Environment and International Inequality', International Affairs, 75, 531-45.

Slaughter, A.-M. (2003), 'Global Government Networks, Global Information Agencies, and Disaggregated Democracy', Michigan Journal of International Law, 24, 1041-75.

Stockholm Conference (1972), Only One Earth, London: Earth Island; distributed by Argus and Robertson.

Stone, C. D. (1972), 'Should Trees Have Standing? Toward Legal Rights for Natural Objects', Southern California Law Review, 45, 450-501.

Stone, C. (1993), The Gnat Is Older than Man: Global Environment and the Human Agenda, Princeton, NJ: Princeton University Press.

Taylor, P. (1986), Respect for Nature: A Theory of Environmental Ethics, Princeton, NJ: Princeton University Press.

Thiong'o, N. (2011), 'Earth Jurisprudence in the African Context', in P. Burdon (ed.), Exploring Wild Law: The Philosophy of Earth Jurisprudence, Kent Town, South Australia: Wakefield Press, 173-9.

Uhlíŕová, K. (2012), 'War Crimes Chamber of the Court of Bosnia and Herzegovina: Seeding “International Standards of Justice"?', in E. Kristjansdottir, A. Nollkaemper and C. Ryngaert (eds), International Law in Domestic Courts: Rule of Law Reform in Post-Conflict States, Cambridge: Intersentia Publishers, 195-217.

Uhlírová, K. (2013), Head of State Immunity in International Law: The Charles Taylor Case before the Special Court for Sierra Leone, Brno: Masaryk University.

Villa, C. J. (2019), 'Gold King Mine Spill: Environmental Law and Legal Protections for Environmental Responders', Utah Law Review, 2019(2), 263-334.

Weiss, E. B. (1989), In Fairness to Future Generations: International Law, Common Patrimony, and Intergenerational Equity, Dobbs Ferry, NY: Transnational Publishers.

Weiss, E. B. (1993), 'International Environmental Law: Contemporary Issues and the Emergence of a New World Order', Georgetown Law Journal, 81, 675-710.

Westra, L. (2011), 'Governance for Integrity? A Distant but Necessary Goal in Exploring Wild Law', in P. Burdon (ed.), Exploring Wild Law: The Philosophy of Earth Jurisprudence, Kent Town, South Australia: Wakefield Press, 324-36.

Wouters, J. and Chanet, L. (2008), 'Corporate Human Rights Responsibility: A European Perspective', Northwestern Journal of International Human Rights, 6, 262-303.

Zaring, D. (2005), 'Informal Procedure, Hard and Soft, in International Administration', Chicago Journal of International Law, 5, 547-93. 


\section{CASES}

Advisory Opinion on Reparation for Injuries Suffered in the Service of the United Nations (1949), ICJ Rep. 174.

Advisory Opinion on the Legality of the Threat or Use of Nuclear Weapons (1996), ICJ Rep. 226.

Ambrogi Melle and Others v. Italy (2019), ECtHR, App. No. 54264/15.

Association Canadienne Contre l'Impunité c. Anvil Mining Limited (2011), Cour Supérieur de Québec. Association Canadienne Contre L'Impunité c. Anvil Mining Limited (2012), Cour d'Appel de Québec. Beanal v. Freeport-McMoran, Inc. 197 F. Supp. 3rd (1999), 161 (5th Cir.).

Case Concerning the Barcelona Traction, Light and Power Company (Belgium v. Spain) (1970), ICJ Rep. 3.

Case Concerning the Gabčikovo-Nagymaros Project (Hungary v. Slovakia) (1997), ICJ Rep. 7.

Certain Activities Carried Out by Nicaragua in the Border Area (Costa Rica v. Nicaragua) (2018), ICJ Rep. 15.

Cordella and Others v. Italy (2019), ECtHR, App. No. 54414/13.

Corfu Channel (UK v. Albania) (1949), ICJ Rep. 4.

Fadeyeva v. Russia (2005), ECtHR, App. No. 55723/00.

Flores v. Southern Peru Copper Corporation 406 F. Supp. 3rd (2003), 65 (2nd Cir.).

Guerra and Others v. Italy (1998), ECtHR, App. No. 14967/89.

Hatton and Others v. United Kingdom (2003), ECtHR [GC], App. No. 36022/97.

Institute for Human Rights and Development in Africa and Others v. Democratic Republic of Congo (2016), African Commission on Human and Peoples' Rights, Communication No. 393/10, accessible at http://www.raid-uk.org/sites/default/files/african_commission_decision_on_kilwa_2017.pdf.

K.M. Chinnappa v. Union of India (2003), WP 202/1995, AIR 2004 SC 724.

Lac Lanoux Arbitration (Spain v. France) (1957), ILR 24, 101.

Locascia and Others v. Italy, ECtHR, App. No. 35648/10.

Lopez Ostra v. Spain (1994), ECtHR, App. No. 16798/90.

Massachusetts et al. v. Environmental Protection Agency et al., No. 05-1120 (2 April 2007).

Mohd. Salim v. State of Uttarakhand \& Others (2017), Writ Petition (PIL) No. 126 of 2014.

Ms Westerhaven Schiffahrts GMBH \& CO KG Redier Shipping BV v. The Attorney General of Belize, Court of Appeal of Belize, A.D. 2011 Civil Appeal No. 19, 2010.

Öneryildiz v. Turkey (2004), ECtHR, App. No. 48939/99.

Sarei v. Rio Tinto 456 F. Supp. 3rd (2006) 1069 (9th Cir.).

Sarei v. Rio Tinto (2007), 8387 (9th Cir. Cal., 12 April 2007).

Sierra Club v. Morton (1972), 405 US 727.

State v. Blue Platinum Ventures Pty Ltd \& Maponya, Case No. RN 126/13 (S.Afr. 2014) Magistrates Court for the Regional Division of Limpopo.

State v. Golfview Mining (Pty) Ltd, ESH 82/11, Ermelo CAS 462/07/2009.

Tătar v. Romania (2009), ECtHR, App. No. 67021/01.

Texaco Overseas Petroleum et al. v. Libyan Arab Republic (1978), ILM 17, 1.

T.N. Godavarman Thirumulpad v. Union of India \& Others (2005), I. A. Nos. 1433 and 1477 of 2005 in Writ Petition (C) (No. 202 of 1995).

Trail Smelter Arbitral Decision (1939), American Journal of International Law, 33, 182.

Trail Smelter Case (United States of America v. Canada) (1941), RIAA III, 1905.

UK Claim, Agreed Final Joint Statement (issued on behalf of all parties to the Trafigura Personal Injury Group Litigation), 2006.

Vellore Citizens Welfare Reform v. Union of India, AIR 1996 SC 2715 (Supreme Court, India).

Yao Esaie Motto \& Others v. Trafigura Limited and Trafigura Beheer BV in the High Court of Justice (2006), Queen's Bench Division, Claim No. HQ06X03370. 


\section{TREATIES AND DOCUMENTS}

Agreement Governing the Activities of States on the Moon and Other Celestial Bodies (1979), ILM 17, 1434.

Bamako Convention on the Ban of the Import into Africa and the Control of Transboundary Movement and Management of Hazardous Wastes within Africa (1991), ILM 30, 773.

Convention between the United States and Other Powers Providing for the Preservation and Protection of Fur Seals (1911), Stat. 37, 1542.

Convention Concerning the Protection of the World Cultural and Natural Heritage (1972), UNTS 1037, 15.

Convention on Biological Diversity (1992), ILM 31, 818.

Convention on International Trade in Endangered Species of Wild Fauna and Flora (1973), UNTS 993, 243.

Convention on the Conservation of Migratory Species of Wild Animals (1979), ILM 19, 15.

Convention on the Prevention of Marine Pollution by Dumping of Wastes and Other Matter (London Convention on Ocean Dumping) (1972) UNTS 1046, 120.

Convention on the Prohibition of the Use, Stockpiling, Production and Transfer of Anti-Personnel Mines and on their Destruction (Ottawa Convention) (1997), ILM 36, 1507.

Convention on Wetlands of International Importance, Especially as Waterfowl Habitat (Ramsar Convention) (1971), ILM 11, 969.

ECE Convention on Long-Range Transboundary Air Pollution (1979), UNTS 1302, 217.

Espoo Convention on Environmental Impact Assessment in a Transboundary Context (Espoo Convention) (1991), ILM 30, 800.

International Convention for the Prevention of Pollution from Ships, 1973, as modified by the Protocol of 1978 relating thereto (MARPOL 73/78), ILM 12, 1319; 17, 546.

Kigali Amendment to the Montreal Protocol on Substances that Deplete the Ozone Layer (2016), C.N.872.2016.TREATIES-XXVII.2.f of 23 November 2016.

Kyoto Protocol to the Framework Convention on Climate Change (1997), ILM 37, 22.

London Amendments to the Protocol on Substances that Deplete the Ozone Layer (1990), ILM 30, 541.

London Convention on the Prevention of Marine Pollution by Dumping of Wastes and Other Matter (1972), UNTS 1046, 120.

Paris Agreement (2015), C.N.63.2016.TREATIES-XXVII.7.d of 16 February 2016.

Protocol on Substances that Deplete the Ozone Layer (1987), UNTS 15, 3; ILM 26, 1550.

Rio Declaration on Environment and Development (1992), ILM 31, 874.

Rome Statute of the International Criminal Court (1998), ILM 37, 999.

Rotterdam Convention on the Prior Informed Consent Procedure for Certain Hazardous Chemicals and Pesticides in International Trade (1998), ILM 38, 1.

Statute of the International Court of Justice (1945), UNTS 33, 993.

Stockholm Convention on Persistent Organic Pollutants (2001), ILM 40, 532.

Stockholm Declaration of the United Nations Conference on the Human Environment (1972), UN Doc. A/Conf. 48/14.

Treaty on Principles Governing the Activities of States in the Exploration and Use of Outer Space, Including the Moon and Other Celestial Bodies (1967), UNTS 610, 205.

United Nations Convention on the Law of the Sea (UNCLOS) (1982), ILM 21, 1261.

United Nations Convention to Combat Desertification (1994), ILM 33, 1328.

United Nations Convention on the Prohibition of Military or any other Hostile Use of Environmental Modification Techniques (1977), UNTS 1108, 151.

United Nations Framework Convention on Climate Change (1992), ILM 31, 849.

Vienna Convention for the Protection of the Ozone Layer (1985), ILM 26, 1529.

Vienna Convention on the Law of Treaties (1969), ILM 8, 679.

Vienna Convention on the Law of Treaties between States and International Organizations or between International Organizations (1986), ILM 25, 543.

World Charter for Nature (1982), ILM 22, 455. 


\section{OTHER SOURCES}

Amnesty International and Greenpeace (2012), 'The Toxic Truth: About a Company Called Trafigura, a Ship Called the Probo Koala, and the Dumping of Toxic Waste in Cote d'Ivoire', Amnesty USA, accessible at https://www.amnestyusa.org/sites/default/les/afr310022012eng.pdf.

Center for International Climate Research (undated), 'The Arctic', accessible at https://cicero.oslo.no/ en/posts/platform/the-arctic.

CIA, 'CIA World Factbook', CIA, accessible at https://www.cia.gov/the-world-factbook/.

Global Catholic Climate Movement (2017), 'April 29: Climate March in Washington, D.C.', accessible at https://catholicclimatemovement.global/april-29/.

Greenwood, C. (2008), 'Sources of International Law: An Introduction', accessible at https://legal.un .org/avl/pdf/ls/greenwood_outline.pdf.

IACmHR (2015), 'Hearing on the Situation of Leaders and Defenders of the Shuar People in Ecuador', Organization of American States, accessible at https://www.oas.org/es/cidh/audiencias/Hearings.aspx ?Lang=en\&Session $=137$.

ICC (2016), 'The ICC Policy Paper on Case Selection and Prioritisation', ICC, accessible at https://www .icc-cpi.int/itemsDocuments/20160915_OTP-Policy_Case Selection_Eng.pdf.

ILA (2004), 'Berlin Rules on Water Resource Law', accessible at: https://ila.vettoreweb.com/Storage/ Download.aspx?DbStorageId=1272\&StorageFileGuid=ce9c1860-f9e5-431b-bd4e-6f98f7028b69.

International Federation for Human Rights (2014), 'Cambodia: ICC Preliminary Examination Requested into Crimes Stemming from Mass Land Grabbing - Press Release' , International Federation for Human Rights, accessible at https://www.fidh.org/en/region/asia/cambodia/16176-cambodia-icc -preliminary-examination-requested-into-crimes-stemming-from.

OECD (2005), Guiding Principles for Regulatory Quality and Performance, accessible at https://www .oecd.org/fr/reformereg/34976533.pdf.

OECD (2010), 'Better Regulation in Europe: Belgium', accessible at https://www.oecd.org/gov/ regulatory-policy/45424282.pdf, 169.

National Parks Act (New Zealand) No. 66 Public Act (17 December 1980).

'Petition to the Inter-American Commission on Human Rights Seeking Relief from Violations Resulting from Global Warming Caused by Acts and Omissions of the United States' (2005), Climate Case Chart, accessible at http://climatecasechart.com/non-us-case/petition-to-the-inter-american -commission-on-human-rights-seeking-relief-from-violations-resulting-from-global-warming-caused -by-acts-and-omissions-of-the-united-states/.

Republic of the Philippines Commission on Human Rights (2017), Press Release, 'Commission on Human Rights of the Philippines Holds Preliminary Meeting Regarding Possible Contributions of Carbon Majors to Climate Change', accessible at https://www.business-humanrights.org/es/\%C3 \%BAltimas-noticias/commission-on-human-rights-of-the-philippines-holds-preliminary-meeting-regarding -possible-contributions-of-carbon-majors-to-climate-change/.

The Corporate Crimes Principles (2016), accessible at https://www.commercecrimehumanrights.org/wp -content/uploads/2016/10/CCHR-0929-Final.pdf.

UN Environment, Africa Office (2016), 'The Kigali Amendment to the Montreal Protocol: Another Global Commitment to Stop Climate Change', accessible at https://www.unep.org/news-and-stories/ news/kigali-amendment-montreal-protocol-another-global-commitment-stop-climate.

United Nations (2016), Report of the International Law Commission, A/71/10, New York: United Nations, accessible at https://legal.un.org/ilc/reports/2016/english/a_71_10.pdf.

United States Federal Water Pollution Control Act Amendments of 1972 (US Clean Water Act). Pub.L. 92-500.

United States of America and Canada, Agreement on Great Lakes Water Quality (1978), No. 18177.

'US-China Joint Announcement on Climate Change' (2014), White House, accessible at https:// obamawhitehouse.archives.gov/the-press-office/2014/11/11/us-china-joint-announcement-climate -change. 